\title{
Jurassic unconformities in the High-Tatric succession, Tatra Mountains, Poland
}

\author{
Anna JEZIERSKA ${ }^{1, *}$ and Piotr ŁUCZYŃSKI ${ }^{1}$ \\ 1 University of Warsaw, Institute of Geology, wirki i Wigury 93, 02-089 Warszawa, Poland
}

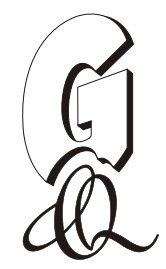

Jezierska, A., Łuczyński, P., 2016. Jurassic unconformities in the High-Tatric succession, Tatra Mountains, Poland. Geological Quarterly, 60 (2): 273-290, doi: 10.7306/gq.1255

During the Triassic/Jurassic boundary interval and in the Jurassic, the Triassic carbonate platforms occupying the northern shelf of the Western Tethys were subjected to disintegration. Record of these processes in the Alpine-Carpathian area is incomplete and contains a number of stratigraphic gaps. In the High-Tatric succession of the Tatra Mountains (Central Western Carpathians) stratigraphic gaps expressed by unconformity surfaces occur between the Triassic and the Middle Jurassic. In particular areas, the Triassic is directly overlain by the Dudziniec Formation (Sinemurian-Bajocian), the Smolegowa Formation (Bajocian), the Krupianka Formation (Bathonian) or the Raptawicka Turnia Formation (Callovian-Hauterivian). The occurrence of Bajocian and Bathonian deposits is limited to isolated lenticular bodies or to infillings of neptunian dykes penetrating the Triassic. Spatial relations between particular Jurassic lithosomes and the occurrence of stratigraphic gaps between particular units allow discerning four main unconformities. In the stratigraphical order these are: base of the Dudziniec Formation (erosional unconformity), base of the Smolegowa Formation (penacordance or paraconformity), base of the Krupianka Formation (erosional unconformity) and base of the Raptawicka Turnia Formation (drowning unconformity). Following episodes of erosion modified the previously developed unconformity surfaces, which resulted in complex modern architecture of the Triassic/Jurassic contact, as well as between particular Jurassic formations.

Key words: unconformities, Triassic, Jurassic, High-Tatric series, Tatra Mountains.

\section{INTRODUCTION}

The Triassic/Jurassic boundary interval and the Jurassic were times of intense palaeogeographical changes in the Central Western Carpathian region. The prevailing extensional regime, related to rifting processes and opening of consecutive ocean basins, led to intensive tectonic activity in various parts of the Tethys Ocean. Opening of the Penninic-Vahic Ocean resulted in the separation of the Alpine-Carpathian region from the stable land of Palaeoeurope (Michalík and Kováč, 1982; Plašienka et al., 1997; Csontos and Vörös, 2004). Extensive carbonate platforms located on continental margins were subjected to disintegration and were replaced by systems of isolated fault-bounded blocks. Individual blocks were subjected to uplift and to differentiated subsidence, leading to a horstgraben morphology of the sea bottom (Santantonio and Carminati, 2011; Plašienka, 2012). Drowned carbonate platforms developed on subsiding blocks, on which shallow-water deposits were replaced by pelagic sediments. Isolated carbonate platforms formed on elevated areas, on which continuation of shallow-water sedimentation took place. The prevailing extensional regime commonly led to the development of submarine fissures

\footnotetext{
*Corresponding author, e-mail: aj.jezierska@gmail.com
}

Received: April 16, 2015; accepted: July 23, 2015; first published online: September 30, 2015 filled by marine deposits - neptunian dykes, and to the formation of internal breccias (Füchtbauer and Richter, 1983; Blendinger, 1986; Plašienka, 1995).

Disintegration of Triassic carbonate platforms took place in many areas located on the northern shelf of the Tethys Ocean. Numerous records of drowned and isolated carbonate platforms are known i.a. from the Southern Alps (Winterer and Bossellini, 1981; Blendinger, 1984, 1986) or from the Apennines (Santantonio, 1993; Cozzi, 2000; Marino and Santantonio, 2010). These examples of disintegrated carbonate platforms, with their characteristic facies successions and accompanying tectonic structures, can be used as reference points when analysing a similar history in different regions.

Sedimentary record of the stratigraphical interval, during which the disintegration of Triassic carbonate platforms took place, contains numerous stratigraphic gaps (Clari et al., 1995; Martire, 1996). Such incomplete record often hinders the reconstruction of depositional conditions in the studied areas, as well as correlation of particular profiles. The spatial relation and contact between strata separated by a stratigraphic gap is generally referred to as "unconformity" or "unconformity surface". Some insight into the processes that took place during the times corresponding to these gaps may come from analyses of these unconformities. Geometrical relations of the strata contacting along the unconformity, the outline and morphology of the unconformity surface itself, facies contrast of the underlying and overlying deposits, and the occurrence of erosional forms and hardgrounds all shed light on the processes that took place in the interval hidden in the gap (Clari et al., 1995; Marino and Santantonio, 2010). For example, it can be deduced if the stud- 
ied area was subjected to emersion and erosion in subaerial conditions, to submarine erosion or faced non-deposition.

Based on the origin of the unconformity surface and geometry of the overlying and underlying strata, various types of unconformities are discerned, such as angular unconformity, penacordance or erosional unconformity. Angular unconformity, also referred to as discordance, takes place when the strata separated by a stratigraphic gap show distinctly different dips and belong to different tectonic stages (Murphy and Salvador, 1994). When the dip difference is in the range of $1-2^{\circ}$, the contact is referred to as penacordant (Łuczyński, 2002). Usually, such contact is difficult to be identified in the field, apart from situations in which it is laterally traced over long distances and a thinning out of particular layers can be observed. Otherwise, it is usually identified only by detailed biostratigraphical analyses. A break in deposition can take place also during drowning of carbonate platforms, in which case a drowning unconformity develops (Schlager and Camber, 1986; Godet, 2013). It is characterized by an abrupt transition from shallow-water carbonates to deep-water clastic or carbonate deposits. A different relation of strata is represented by an erosional unconformity, in which the strata below and above the unconformity surface are parallel to each other but separated by an erosional surface. The stratigraphic gap is in such case an effect of removal of deposits from elevated areas (Clari et al., 1995). Long-lasting erosion may lead to removal of the whole thickness of some deposits in some areas and their preservation only as isolated lenses (Murphy and Salvador, 1994). Usually, the deposits resting on the erosional surface contain clasts from the underlying eroded deposits.

Stratigraphic gaps embracing the times of intense palaeogeographical changes on the northern shelf of the Tethys Ocean are present also in the sedimentary succession of the Tatra Mountains in Central Western Carpathians (southern Poland). Unconformities at the base of the Jurassic and between particular Jurassic stratigraphical units occur in a number of tectonic units. So far, only a generalized model of development of the area in the discussed interval has been presented (Łuczyński, 2002). However, the picture is internally complex, with particular areas differing in the range of stratigraphic gaps and in spatial relations between given lithosomes. This paper presents a more detailed scenario of the development of unconformities in the area.

\section{GEOLOGICAL SETTING}

The Tatra Mountains are the northernmost area of the so-called core mountains of the Central Western Carpathians (Fig. 1A). Sedimentary cover of the Variscan crystalline massif is composed of Permian to Cretaceous (Turonian) deposits representing two major successions (or series) - High-Tatric and Sub-Tatric, which substantially differ in their completeness and facies development. The High-Tatric succession is generally characterized by shallow water facies with numerous stratigraphic gaps. The Sub-Tatric series is stratigraphically more complete and is composed of deeper facies. The present studies were carried out in the High-Tatric succession. Andrusov et al. (1973) introduced a tectonic division of the Central Carpathians, according to which the High-Tatric succession corresponds to the Tatric unit, whereas the Sub-Tatric succession to the Fatric and Hronic units.

The High-Tatric succession is exposed in three tectonic units: Kominy Tylkowe, Czerwone Wierchy and Giewont (Fig. 1B; e.g., Kotański, 1961). The Kominy Tylkowe Unit (also called the autochthonous unit) rests directly on the crystalline basement (e.g., Passendorfer, 1961). The unit embraces also the so-called parautochthonous folds, in which the sediments have been tectonically moved on minor distances, but palaeogeographically represent the same region. The Czerwone Wierchy and Giewont units (also called allochthonous or foldic) have been detached from their basement and transported northwards over the autochthonous unit as High-Tatric nappes (e.g., Jurewicz, 2005). Palaeogeographically, they represent areas situated south of the autochthonous series. The Sub-Tatric succession is exposed on the northern slopes of the Tatra Mountains and builds two Sub-Tatric nappes: Krížna (Lower Sub-Tatric or Fatric) and Choč (Upper Sub-Tatric or Hronic) (e.g., Gaździcki and Michalík, 1980). Originally, the deposits of the Sub-Tatric succession accumulated south of the High-Tatric area. The formation and northward propagation of nappes took place in the Late Cretaceous, beneath the sea and under high overburden pressures in short episodes of movement, separated by periods of tectonic stability. First, the Choč Nappe was thrust over the Krížna Nappe, and later the High-Tatric units were thrust beneath the Sub-Tatric nappes (Jurewicz, 2005, 2012).

The High-Tatric Jurassic is organized into lithostratigraphic units (Lefeld et al., 1985). The Dudziniec Formation is of Lower Jurassic and the lowermost part of Middle Jurassic (Aalenian) age, the Smolegowa and Krupianka formations are respectively of Bajocian and Bathonian age, and the Raptawicka Turnia Formation is of Callovian up to Turonian age (Fig. 2).

The Dudziniec Formation is developed mainly as sandy-crinoidal facies (Wójcik, 1981). The detrital material is composed of quartz grains, carbonate lithoclasts and scattered bioclasts (bivalves, crinoids, brachiopods and belemnites). The age of the formation, based on belemnite and brachiopod fauna, has been determined for Sinemurian-Bajocian (Horwitz and Rabowski, 1922; Lefeld et al., 1985). It is overlain by crinoidal limestones of the Smolegowa and Krupianka formations. The names of these formations have been adopted into the High-Tatric lithostratigraphic scheme from the division made for the Pieniny Klippen Belt (Birkenmajer, 1977; Lefeld et al., 1985). The Smolegowa Formation is developed as light grey and pinkish crinoidal limestones. Based on brachiopod fauna the age of this formation has been determined as Bajocian (Horwitz and Rabowski, 1922). The overlying Krupianka Formation is represented by red and pink crinoidal limestones, nodular limestones and ferruginous limestones. Its age, based on ammonite fauna, has been determined as Bathonian (Passendorfer, 1935, 1938). The Raptawicka Turnia Formation starts with Callovian wavy bedded limestones and Oxfordian nodular and massive limestones, upper passing into thick massive limestones. The formation yielded Callovian (Horwitz and Rabowski, 1922) and Kimmeridgian (Passendorfer, 1928) fauna, and is assumed to represent an interval from the Callovian up to Hauterivian (Lefeld et al., 1985).

The most complete profile of the High-Tatric succession is exposed in the autochthonous (Kominy Tylkowe) unit, whereas in the allochthonous units and in the parautochthonous folds it abounds in stratigraphic gaps, and in most places in the complete lack of Upper Triassic and Lower Jurassic deposits. The Middle Triassic (Anisian) in these areas is directly overlain by the Smolegowa, Krupianka or even Raptawicka Turnia formations. In the Czerwone Wierchy Unit the gaps are best pronounced, but there is no locality in which all these formations would be present in a single profile. Commonly, the only indication of deposition of the sediments of particular formations on the given area is their occurrence in neptunian dykes cutting the Triassic (Łuczyński, 2001a). 


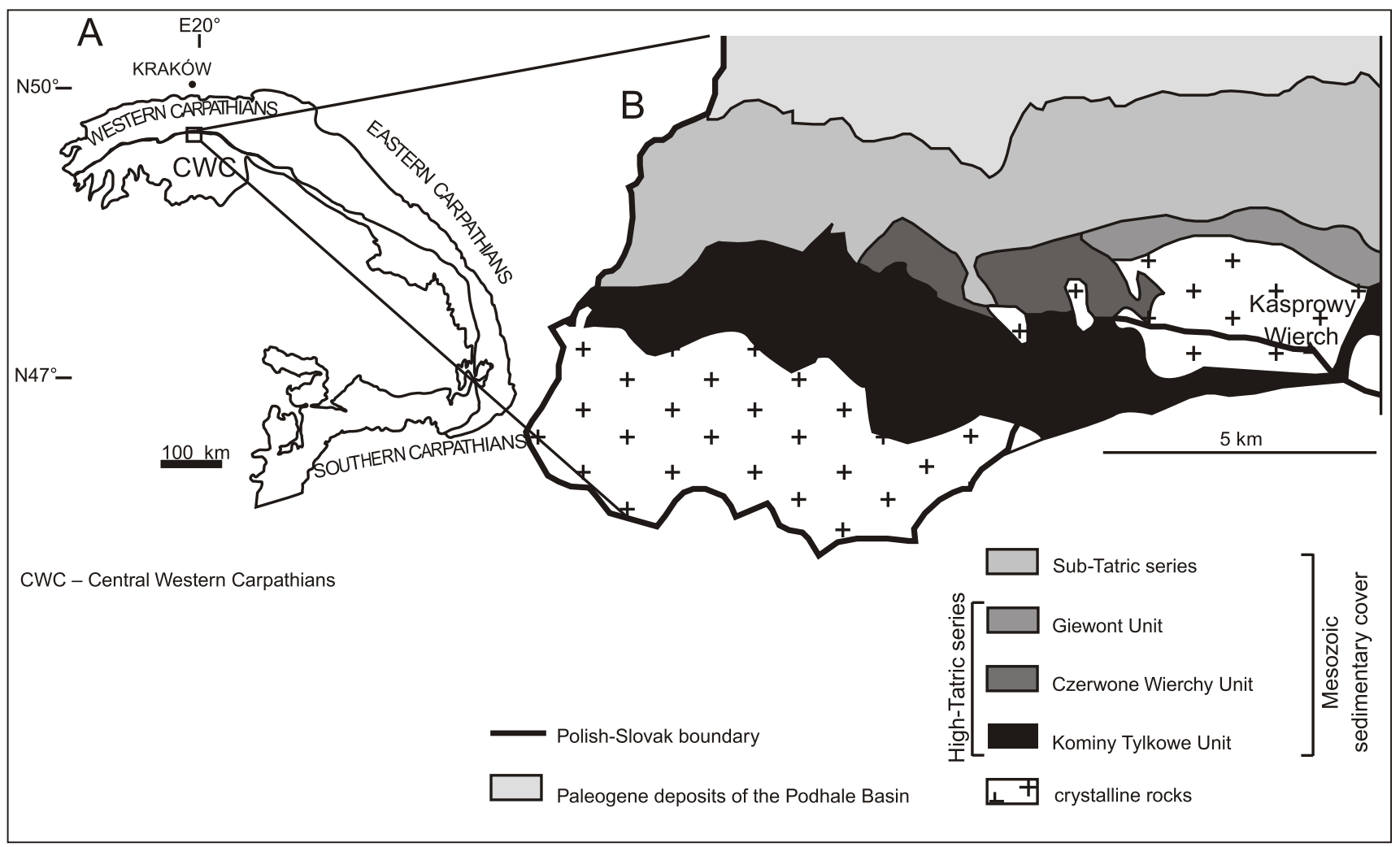

Fig. 1. Structural map of the western part the Polish section of the Tatra Massif (B; after Łuczyński, 2001a), and their geographical location within the Carpathians (A)

\section{MATERIALS AND METHODS}

The exposures, in which the contact between the HighTatric Triassic and Jurassic deposits was accessible for studies, were selected based on the analysis of data published by Rabowski (1959), Kotański (1959a) and Bac-Moszaszwili et al. (1979). Photographical field documentation, available in works on the geological structure of particular parts of the High-Tatric area (e.g., Radwański, 1959; Grochocka-Rećko, 1963; Kostiukow, 1963; Szulczewski, 1963), also proved to be exceptionally useful.

In all three High-Tatric units (Kominy Tylkowe, Czerwone Wierchy and Giewont) the analysed profiles are arranged along lines running roughly W-E (Fig. 3). In the autochthonous unit, the studied profiles are located in the area between the Kościeliska Valley on the west, through the Wąwóz Kraków gorge, to the slopes of Ciemniak summit on the east. The work in this unit concentrated in the parautochthonous folds (Rzędy pod Ciemniakiem) and in those areas that lack a continuous thick cover of the Dudziniec Formation (Wąwóz Kraków gorge). The unit is represented by five profiles (Fig. 4): Wąwóz Kraków gorge 1 and 2 (1WK, 2WK) and Rzędy pod Ciemniakiem 1, 2 and 3 (1RZ, 2RZ and 3RZ). In the Czerwone Wierchy Unit the exposures are located between the Kościeliska Valley on the west to $\mathrm{Ni}$ nia Świstówka in the Mała Łaka Valley on the east. Eight profiles were analysed in this unit (Fig. 5): Brama Kraszewskiego (BK), Mała Świstówka (MŚ), Świstówka Passendorfera (SP), Wielka Świstówka 1 and 2 (1WŚ, 2WŚ), Kobylarzowy leb 1 and $2(1 \mathrm{~K}, 2 \mathrm{~K})$ and Ni nia Świstówka (NŚ). In the Giewont Unit the exposures are located in the Giewont and Zawrat Kasprowy massifs. The unit is represented by nine profiles (Fig. 6) - six in the Giewont area: in the vicinity of a touristic trail to the summit (Gst), on Długi Giewont (1G, 2G and 3G) and near the Wrótka Pass (1GW, 2GW), and three in the Zawrat Kasprowy area (1ZK, 2ZK and 3ZK).

The presented profiles embrace the Triassic/Jurassic contact and the Jurassic formations resting on the Triassic. The age ascriptions in particular profiles were made according to the lithostratigraphic scheme presented by Lefeld et al. (1985). However, age determinations of the Jurassic formations of the High-Tatric series are based only on scarce fauna findings from single exposures. The formation boundaries are thus most probably diachronous and do not strictly correspond to chronostratigraphic boundaries. The ascription of particular formations to certain ages is therefore a simplification, based mainly on lithological analogies. In the present work, consecutive Jurassic formations are identified with particular chronostratigraphical ages: Dudziniec Formation - Sinemurian-Aalenian, Smolegowa Formation - Bajocian, Krupianka Formation - Bathonian and Raptawicka Turnia Formation - Callovian-Hauterivian. Due to the occurrence of numerous gaps, and therefore to the incompleteness of the stratigraphical record, the deposits referred to in various profiles as representing the same formation do not have to be exact time equivalents.

All the unconformity surfaces between the Triassic and the Jurassic and between particular Jurassic formations were traced in the field. Special attention was paid to the relative geometry of the strata below and over the contact, identification of erosional structures, occurrence of ferruginous coats and of neptunian dykes. The range of the stratigraphic gap in the profiles was determined by the absence of particular formations ascribed to certain ages (see above), and included parts of the contacting units. For example, if the Anisian is overlain directly by the Smolegowa Formation (Bajocian), the stratigraphic gap is referred to as Anisian to Bajocian 


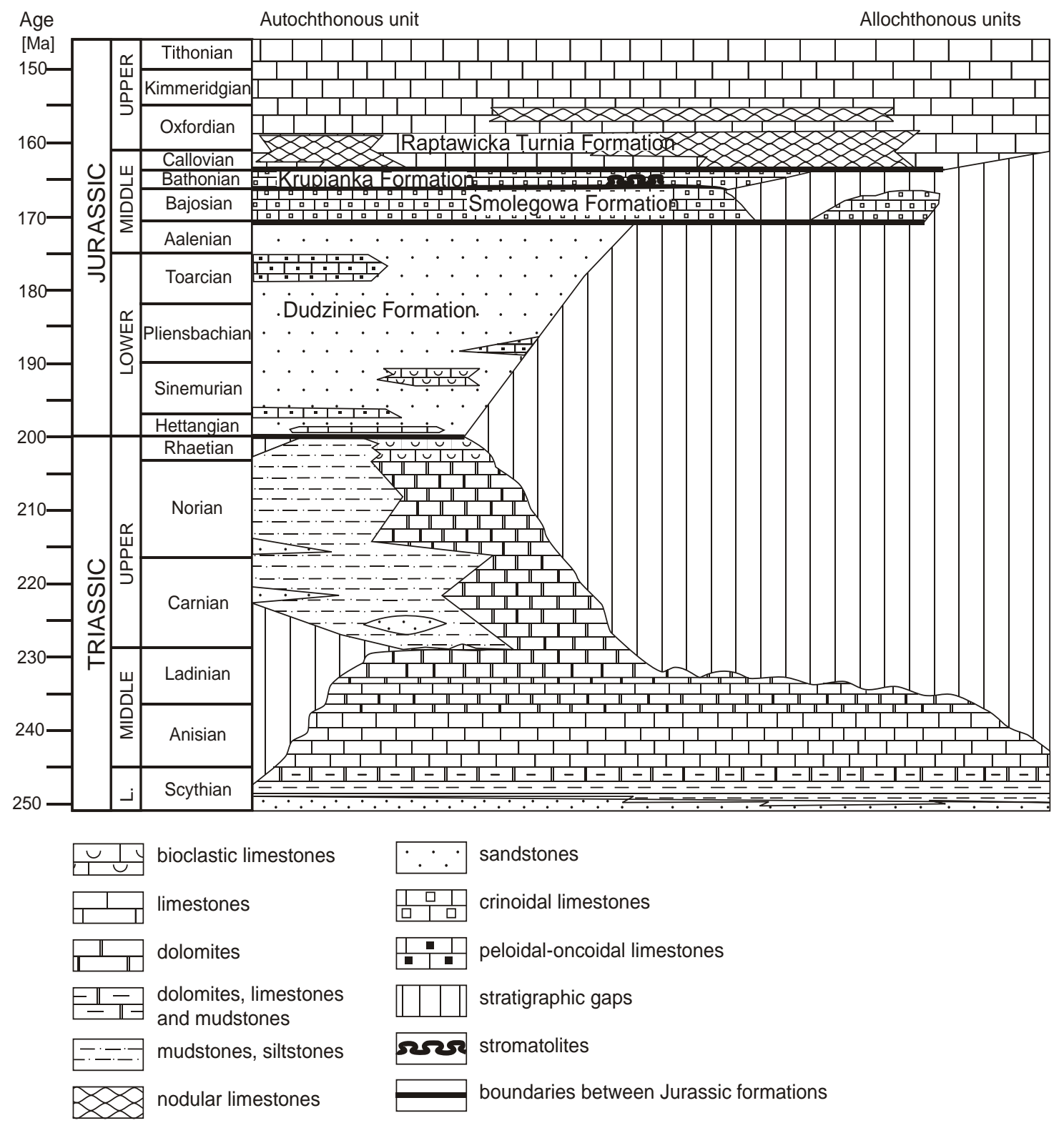

Fig. 2. Lithostratigraphic units of the High-Tatric series (after Uchman, 2014)

Thin sections were made from distinct selected lithologies. The identified characteristic microfacies were described according to Dunham (1962) classification.

For the deposits of the Smolegowa and Krupianka formations, quantitative analysis of clastic admixture has also been made. Due to the character of the extraclasts, a routinely used method of analysing the terrigenous admixture in limestones by studying the insoluble residue after leaching the rock in acetic acid could not be directly applied. Along with insoluble quartz and ferruginous clasts, both formations contain abundant lithoclasts of soluble limestones and dolomites. Therefore, the studies were based mainly on the observations of thin sections, and to some extent also of rocks in the field. The amounts of the insoluble component obtained from these rocks were used, however, to compare the amount of quartz grains determined by the two methods. Knowing the weight percentage of quartz grains versus the weight of the whole rock sample calculated from the insoluble residue, and approximating the quantitative relations between particular types of grains, it was possible to roughly determine the amounts of other types of lithoclasts. The identification of clastic admixture provided clues on the possible source areas.

\section{JURASSIC UNCONFORMITIES OF THE HIGH-TATRIC AREA - DESCRIPTION}

In the High-Tatric series, the Triassic is in various areas overlain by different Jurassic formations. A complete succession of Triassic and Jurassic deposits occurs only in the Kominy Tylkowe Unit (Rabowski, 1959; Kotański, 1959b). Spatial relations between particular Jurassic units (Fig. 7) indicate that the stratigraphic gaps and the corresponding unconformities are an effect of a number of processes. Four main unconformities have been identified:

- at the base of the Dudziniec Formation (only in the autochthonous unit); 


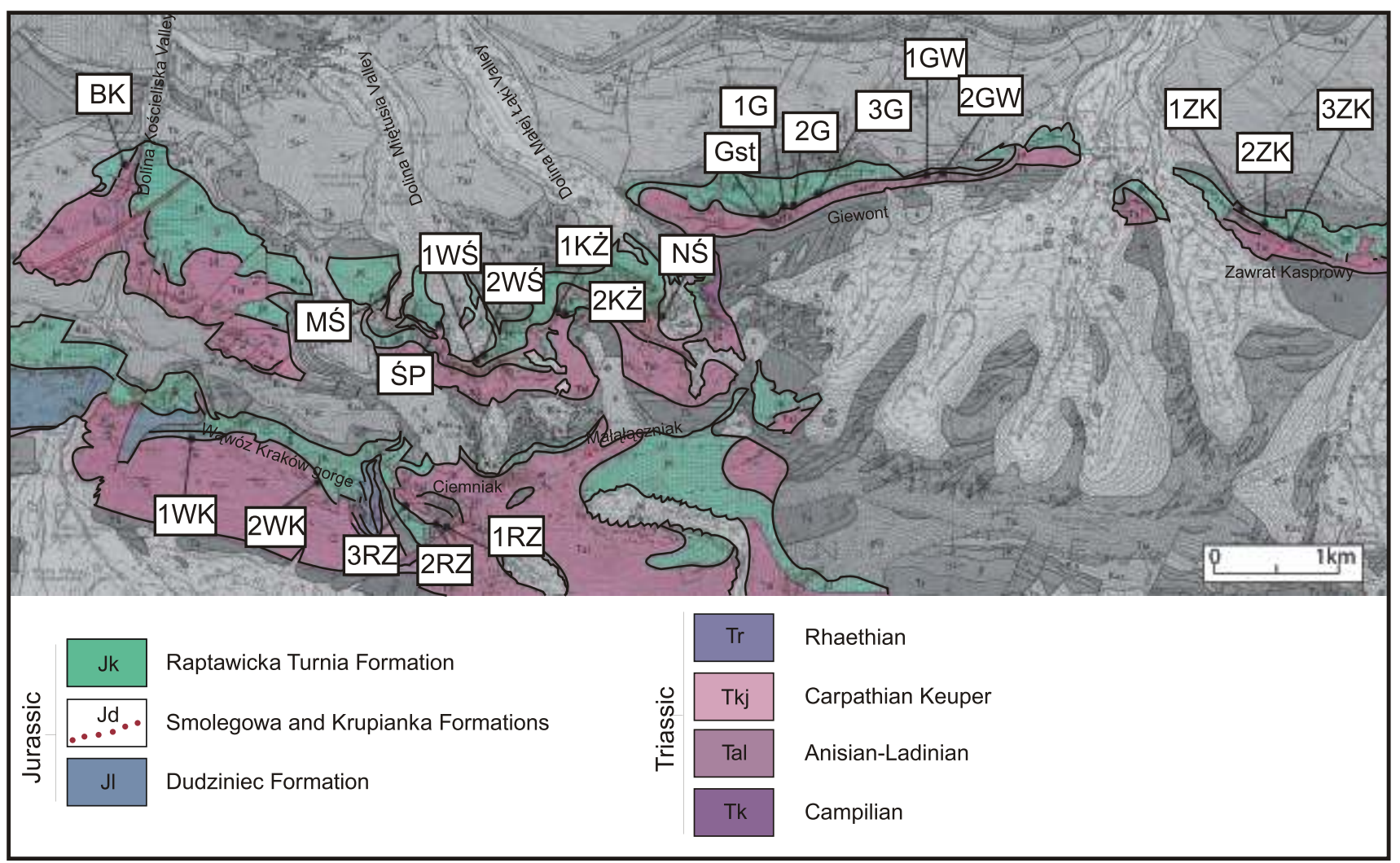

Fig. 3. Geological map (after Bac-Moszaszwili et al., 1979) of the High-Tatric series with location of profiles

WK - Wąwóz Kraków gorge, RZ - Rzędy pod Ciemniakiem, BK - Brama Kraszewskiego, MŚ - Mała Świstówka, ŚP - Świstówka Passendorfera, WŚ - Wielka Świstówka, K - Kobylarzowy leb, NŚ - Ni nia Świstówka, Gst - Giewont touristic trail, G - Długi Giewont, GW - Giewont Wrótka, ZK - Zawrat Kasprowy

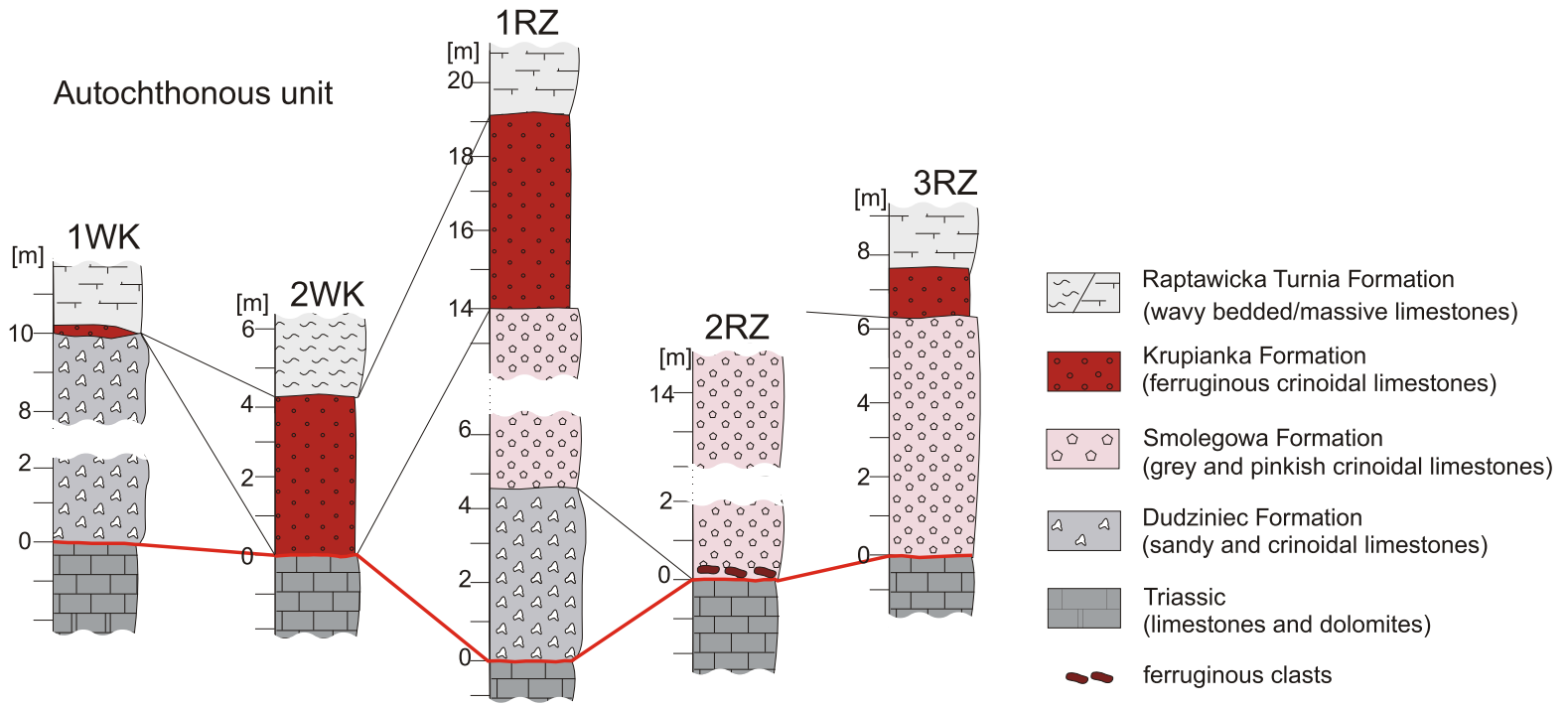

Fig. 4. Selected profiles of the autochthonous unit

Point " 0 " on the vertical scale in all the profiles is the base of the Jurassic, for other explanations see Figure 3 


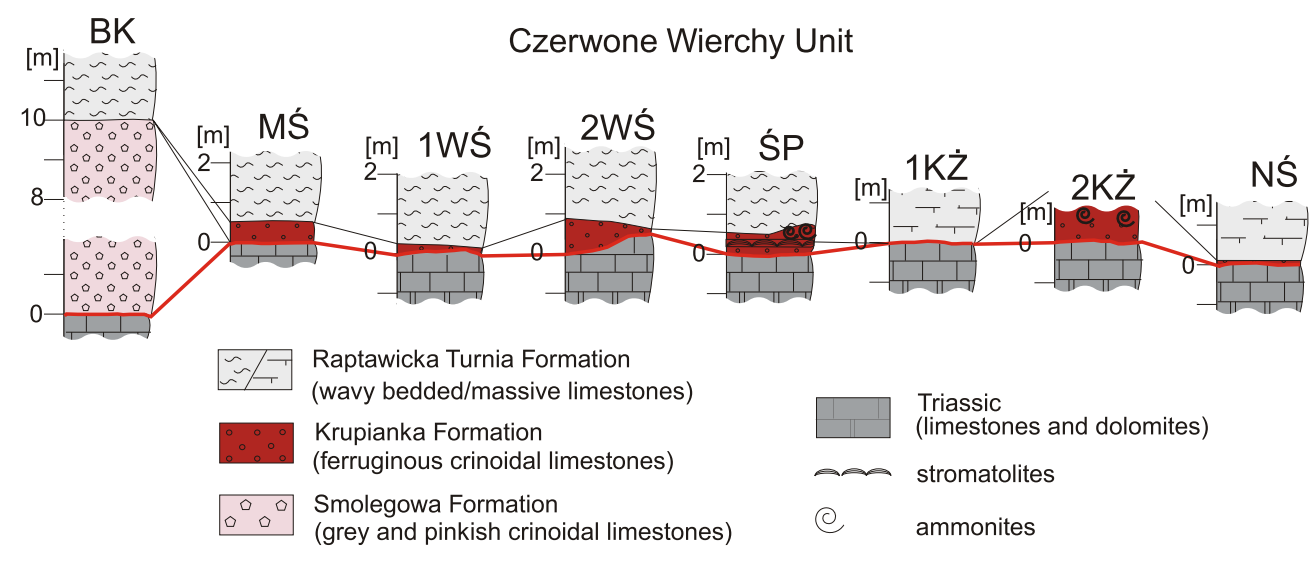

Fig. 5. Selected profiles of the Czerwone Wierchy Unit

For explanations see Figure 3

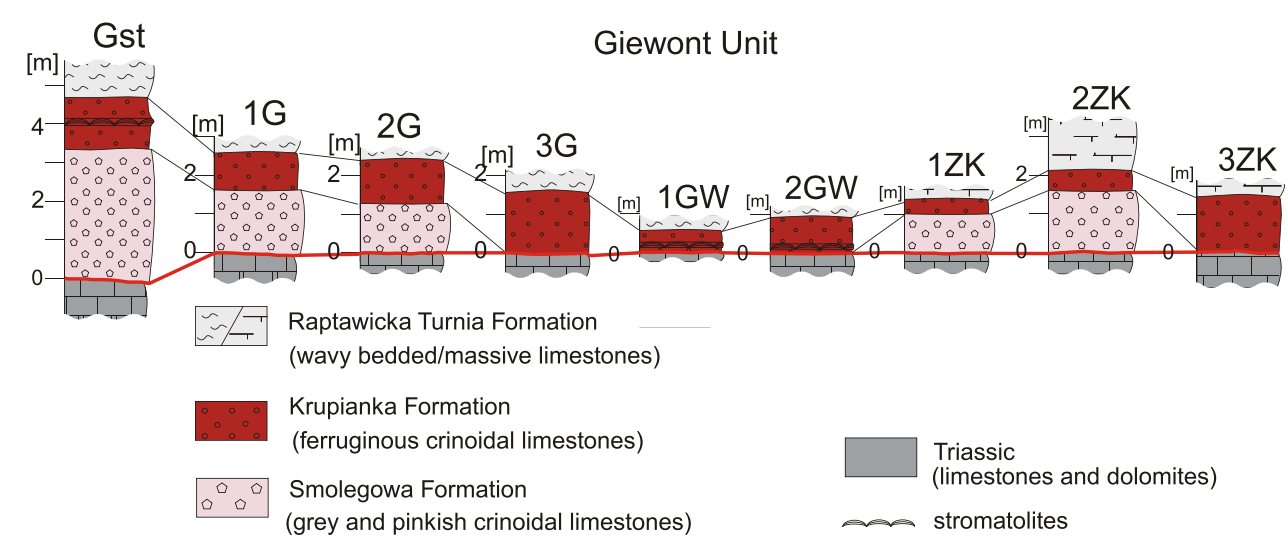

Fig. 6. Selected profiles of the Giewont Unit

For explanations see Figure 3

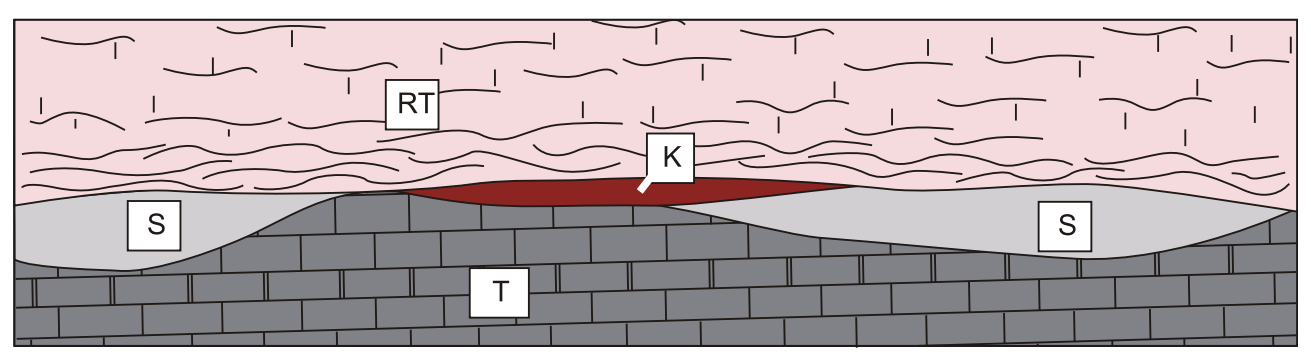

Fig. 7. Schematic spatial relation between particular Jurassic formations in the High-Tatric allochthonous units

$\mathrm{T}$ - Triassic, S - Smolegowa Formation (Bajocian), K - Krupianka Formation (Bathonian), RT - Lower part of Raptawicka Turnia Formation (Callovian-Oxfordian)

- at the base of the Smolegowa Formation;

- at the base of the Krupianka Formation;

- at the base of the Raptawicka Turnia Formation.

Moreover, prominent sedimentary discontinuities are present also within the Krupianka Formation.

\section{DUDZINIEC FORMATION \\ AND THE UNCONFORMITY AT ITS BASE}

The Dudziniec Formation outcrops only in the autochthonous unit. Its contact with the Triassic has been studied only in the western part of the area - in the Wąwóz Kraków gorge (Fig. 4, 
profile 1WK) and Rzędy pod Ciemniakiem (Fig. 4, profile 1RZ), in which the formation has a limited thickness and its occurrence is spatially limited only to isolated exposures (Fig. 8A). The Dudziniec Formation is developed mainly as faintly bedded sandy and crinoidal limestones (Wójcik, 1981). In the studied profiles it is represented by quartz-lithoclast grainstones with crinoids (Fig. 9A). The lithoclasts of the sandy limestones are characterized by various fractions in different exposures. In the Rzędy pod Ciemniakiem they reach a diameter of a few centimetres, while in the Wąwóz Kraków gorge the size of the clasts usually does not exceed $0.5 \mathrm{~cm}$. The formation contains also intraclasts of sandy and crinoidal limestones coming from reworking of previously deposited Lower Jurassic sediments. Differences in the development of the Lower Jurassic between particular isolated exposures hinder their precise correlation.

The unconformity between the Triassic and the Jurassic runs at the base of the Dudziniec Formation. The surface is uneven and has a clearly erosional character (Fig. 10). In the scale of particular exposures, the unconformity surface runs roughly parallel to the bedding in the Triassic, and therefore a potential penacordant contact cannot be identified.

SMOLEGOWA FORMATION AND THE UNCONFORMITY AT ITS BASE

The Smolegowa Formation in the Tatra Mountains is developed as grey, in places pinkish crinoidal limestone with indistinct bedding (Fig. 8B). The rock is composed of recrystallised crinoids represented mainly by individual ossicles, commonly with preserved pentagonal or circular shapes, with typical dimensions ranging between 0.5 and $1.5 \mathrm{~cm}$, sometimes accompanied by longer unseparated columns. In places it contains also debris of brachiopod shells and a small admixture of terrigenous material. The formation is uniformly developed in the whole High-Tatric area. Only in the Rzędy pod Ciemniakiem region, its bottom part is characterized by the occurrence of relatively large ferruginous clasts and carbonate clasts with ferruginous coats (Fig. 9C), with diameters exceeding $1 \mathrm{~cm}$, which may indicate breaks in deposition and development of omission surfaces (comp. Jach et al., 2014). The Smolegowa Formation is represented mainly by crinoidal grainstones (Fig. 9B), subordinately also by crinoidal, crinoidal-brachiopod, and crinoidal-peloidal packstones and wackestones.
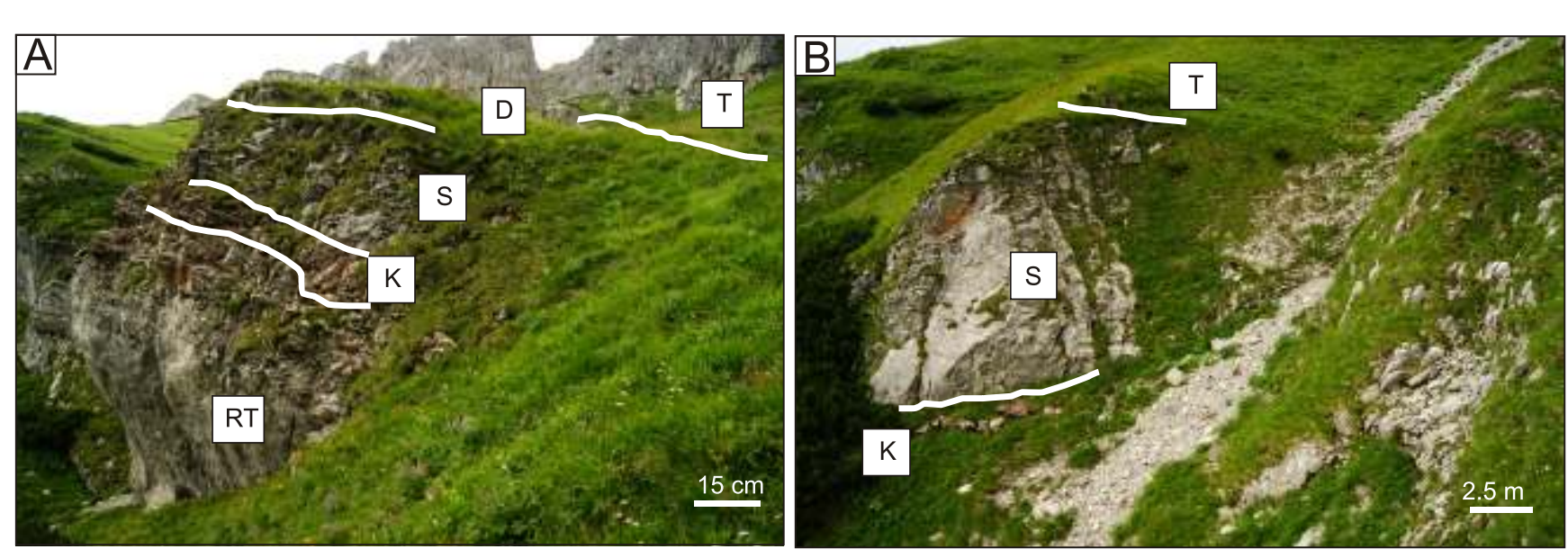

Apart from crinoidal fragments, the deposits contain an admixture of lithoclasts derived from the High-Tatric Triassic succession (limestones and dolomites), in places accompanied by quartz grains, and fragments of bivalves and sponge spicules (Lefeld et al., 1985). The terrigenous admixture analysis shows that the extraclast contents in the Smolegowa Formation range between around 1\% in the Czerwone Wierchy Unit up to 3.7\% in the eastern part of the autochthonous unit. Also the clast composition varies between particular tectonic units (Fig. 11A). In the autochthonous unit, most common are quartz grains (40\%) accompanied by limestone lithoclasts (35\%), whereas in the Giewont Unit, limestone lithoclasts constitute $60 \%$ of the terrigenous material and the quartz grains only $15 \%$. In the Czerwone Wierchy Unit the clastic material is composed solely of limestone lithoclasts.

The unconformity at the base of the Smolegowa Formation occurs in all three High-Tatric tectonic units. Over the whole study area it has an erosional character (Fig. 12C), as indicated e.g., by the occurrence of coarse terrigenous material at the base of the formation in Rzędy pod Ciemniakiem (Fig. 4, profile 2RZ). In the scale of particular exposures the contact between the Triassic and the Jurassic runs roughly parallel to the bedding in the Triassic strata. Only in the Giewont Unit, in which the contact can be traced in a continuous transect along longer distances, a penacordant contact could be identified, with consecutively older Triassic layers westwards underlying the Bajocian (Fig. 13).

The occurrence of Bajocian crinoidal limestones is restricted to isolated lenses (Fig. 7), the thickness of which varies between a few and several metres. The greatest thickness in the analysed profiles occurs in the eastern part of the autochthonous unit - in Rzędy pod Ciemniakiem (Figs. 4 and 8), where it exceeds 15 metres. A roughly similar thickness is recorded also in Brama Kraszewskiego (Fig. 5, profile BK) and in Wy nia Świstówka in the Mała Łąka Valley (Grochocka-Rećko, 1963). These two localities are the only exposures of the Smolegowa Formation in the Czerwone Wierchy Unit. In the Giewont Unit, the formation occurs only in small lenses with the maximum thickness of 1.0-2.5 m. In all three units, in areas where the Smolegowa Formation is absent in the normal stratigraphical column, its deposits can be found in neptunian dykes penetrating the Triassic, as is the case e.g., in the Wąwóz Kraków gorge.

Fig. 8. Jurassic lithosomes in Rzędy pod Ciemniakiem

1 (1RZ); B - Rzędy pod Ciemniakiem 2 (2RZ); T - Triassic, D - Dudziniec Formation, A - Rzędy pod Ciemniakiem 1 (1RZ); B - Rzędy pod Ciemniakiem 2 (2RZ); T - Triassic, D - Dudziniec Formation,
K - Krupianka Formation, RT - Raptawicka Turnia Formation, S - Smolegowa Formation, profile in reversed position 

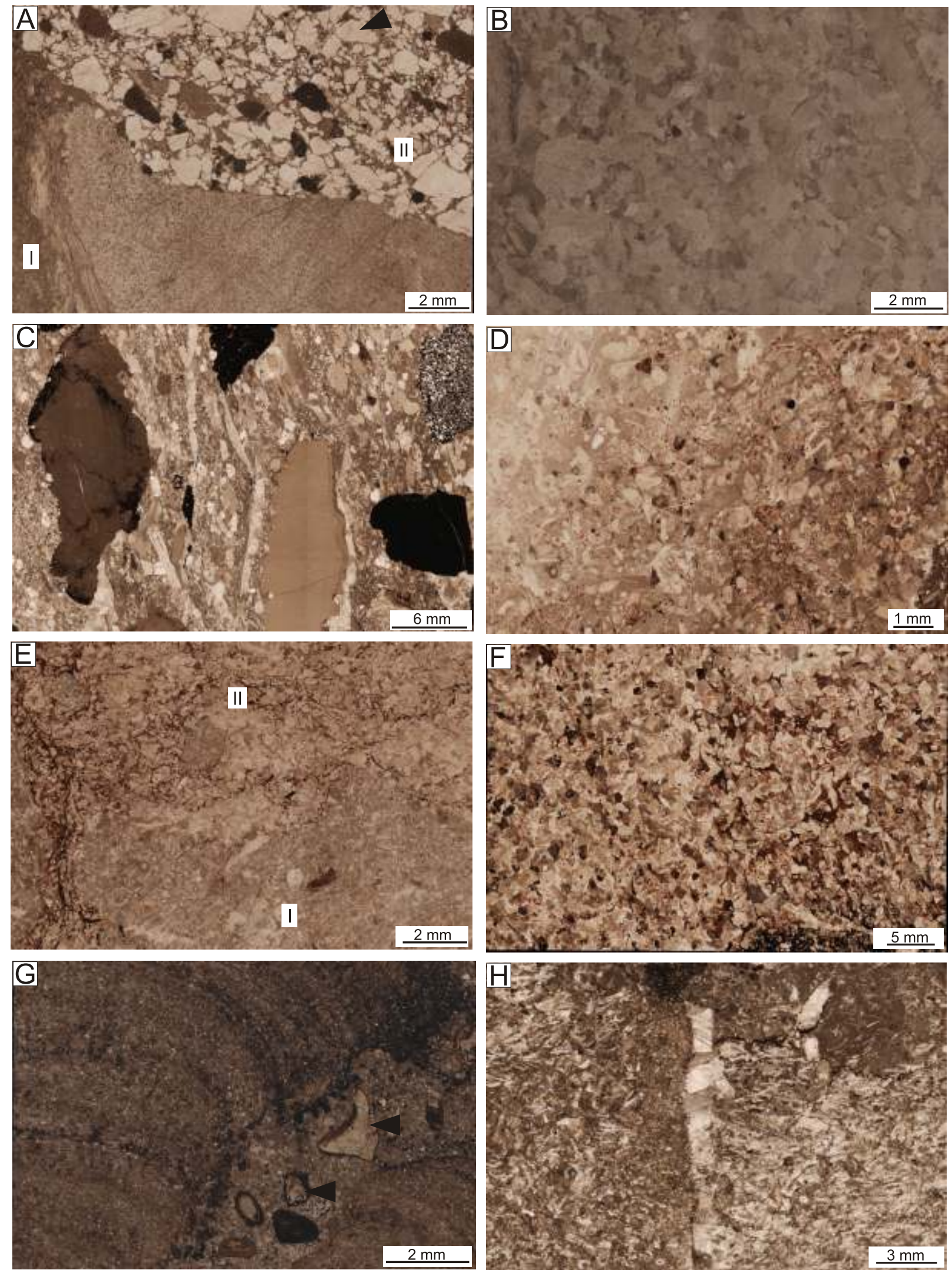

Fig. 9. Microfacies of the High-Tatric Lower and Middle Jurassic

A - contact of the Triassic (I) and the Dudziniec Formation (II) developed as quartz-lithoclast grainstone with crinoids, Wąwóz Kraków gorge 1; B - crinoidal grainstone, Smolegowa Formation, Rzędy pod Ciemnakiem 1; C - quartz-lithoclast rudstone with crinoids and ferruginous clasts, Smolegowa Formation, Rzędy pod Ciemniakiem 2; D - crinoidal packstone with ferruginous clasts, Krupianka Formation, Rzędy pod Ciemnakiem 1; E - crinoidal wackestone (I) and crinoidal packstone (II), Krupianka Formation, Wąwóz Kraków gorge 2; F - crinoidal grainstone, Krupianka Formation, Wielka Świstówka 1; G - stromatolite boundstone with lithoclasts, Krupianka Formation, Świstówka Passendorfera; H - filamentous wackestone/packstone, Raptawicka Turnia Formation, Wielka Świstówka 1 


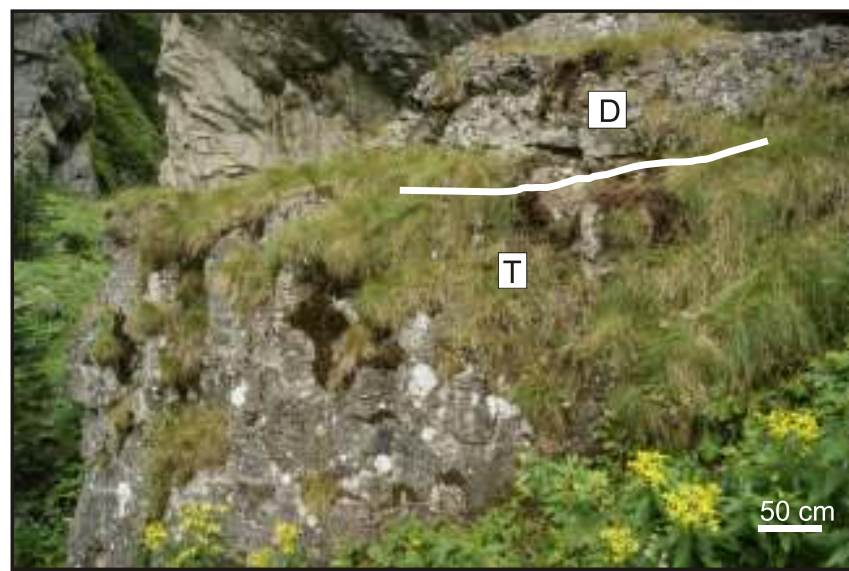

Fig. 10. Erosional surface at the base of the Dudziniec Formation; Wąwóz Kraków gorge 1 (1WK)

T - Triassic, D - Dudziniec Formation

KRUPIANKA FORMATION

AND THE UNCONFORMITY AT ITS BASE

The Krupianka Formation is represented by three main lithofacies: ferruginous, crinoidal and nodular (stylonodular) limestones. All three varieties are characterized by a distinct red colour (Fig. 14B) associated with ferruginous minerals dispersed in the rocks, and by a rich admixture of terrigenous material. Ferruginous and stylonodular limestones owe their modern development to pressure-solution processes (Łuczyński, $2001 b)$. The ferruginous limestones are highly enriched in elements resistant to dissolution. The stylonodular structure formed by selective dissolution of nodular limestones. Pre-compactional differences between the Krupianka Formation lithofacies were less evident than they are today.

Bathonian crinoidal limestones occur in all units of the High-Tatric series. They distinctly differ from their counterparts of the Smolegowa Formation. Main differences are in size, abundance and preservation state of crinoidal fragments, as well as in a higher admixture of terrigenous material. Crinoid ossicles of the Krupianka Formation are broken and their size does not exceed $0.5 \mathrm{~cm}$. The highest content of crinoidal material is characteristic for the Giewont Unit, in which also brachiopods and belemnites, as well as stromatolites are common (Fig. 6, profiles Gst, 1GW, 2GW). Crinoidal limestones of the Krupianka Formation are represented by crinoidal packstones and wackestones (Fig. 9D-E), more seldom by crinoidal and crinoidal-lithoclast grainstones (Fig. 9F). Common are also intervals with mass occurrence of filaments - fragments of thin-shelled bivalves, most probably of the genus Bositra. Foraminifers and calcareous algae are the most typical subordinate components. The analysis of thin sections reveals also common occurrence of effects of chemical dissolution, such as stylolites and dissolution seams.

Ferruginous limestones of the Krupianka Formation outcrop only in the Czerwone Wierchy Unit, and show a distinct variability. In Świstówka Passendorfera they are represented by ferruginous cephalopod limestones with a rich ammonite fauna resting on a stromatolitic horizon, several centimetres thick (Fig. 5, profile ŚP; Fig. 15A). Interstices between stromatolite domes are filled with rich terrigenous material composed mainly of limestones and dolomites derived from the Triassic (Figs. 9G and 15A). In Mała and Wielka Świstówka the ferruginous limestones contain crinoids that constitute up to $30 \%$ of the rock.
Very common are dissolution structures, developed mainly as dissolution seams and concentrations of insoluble components, such as ferruginous minerals and quartz grains. The limestones are represented mainly by crinoidal, crinoidal-lithoclast, and filamentous wackestones, and rarely by crinoidal packstones.

The nodular limestones show a stylonodular structure with internodular areas strongly penetrated by dissolution seams. Crinoids, brachiopods and belemnites are the main macrofaunal components. The microfacies are represented mainly by crinoidal, crinoidal-brachiopod, and filamentous wackestones. The Krupianka nodular limestones are most common in the autochthonous unit.

The Bathonian deposits distinctly differ between particular lithofacies and tectonic units in the amount of terrigenous material and its contents (Fig. 11B). The highest amounts of terrigenous material are present in the eastern part of the autochthonous unit (up to 16\%), and the lowest - in the Giewont Unit $(5 \%)$. In the studied profiles of the autochthonous unit, $45 \%$ of the admixture is represented by quartz grains, $30 \%$ by limestone lithoclasts, and respectively 15 and $10 \%$ by ferruginous clasts and dolomites. In the Czerwone Wierchy Unit the most common component of the admixture is ferruginous lithoclasts $(40 \%)$, while in the Giewont Unit, quartz, limestone, dolomite and ferruginous grains each constitute $25 \%$ of the admixture.

The unconformity at the bottom of the Krupianka Formation shows a great spatial variability, mainly due to different development of the overlying deposits. The stratigraphic gap in particular exposures embraces the Anisian-Bathonian, Aalenian-Bathonian or of just the Bajocian-Bathonian interval. The occurrence of the Krupianka Formation in all tectonic units of the High-Tatric series is limited to isolated lenticular bodies, with the maximum thickness reaching 5 metres in the autochthonous unit (Fig. 4, profiles 2WK, 1RZ). In all cases the contact shows an erosional character, underlined by lenticular shapes of the lithosomes (Fig. 14). In many places, the Bathonian deposits fill local depressions. The Krupianka Formation is characterized also by the occurrence of internal discontinuities underlined by erosional surfaces and/or ferruginous coats.

RAPTAWICKA TURNIA FORMATION AND THE UNCONFORMITY AT ITS BASE

In its lowermost part (Callovian) the Raptawicka Turnia Formation is developed as wavy bedded, light pink or grey limestones with marly and silty intercalations (Fig. 15C). The Callovian yields belemnites, in places accompanied by poorly preserved ammonites. The rocks abound in dissolution structures. The microfacies are represented by filamentous and filamentous-peloidal mudstones (Fig. 9H).

In most places the contact at the base of the Raptawicka Turnia Formation with the underlying rocks is erosional. In some profiles the boundary is underlined by ferruginous coats. The stratigraphic gap associated with this unconformity is greatest in Kobylarzowy leb (Fig. 5, profile $1 \mathrm{~K}$ ) in the Czerwone Wierchy Unit (Anisian-Callovian), where the Raptawicka Turnia Formation rests directly on the Middle Triassic. In most other areas the gap embraces the interval limited to Bajocian-Callovian or Bathonian-Callovian.

\section{INTERPRETATION}

The High-Tatric profiles contain a number of variously developed unconformity surfaces that formed in several distinct 
A Smolegowa Formation
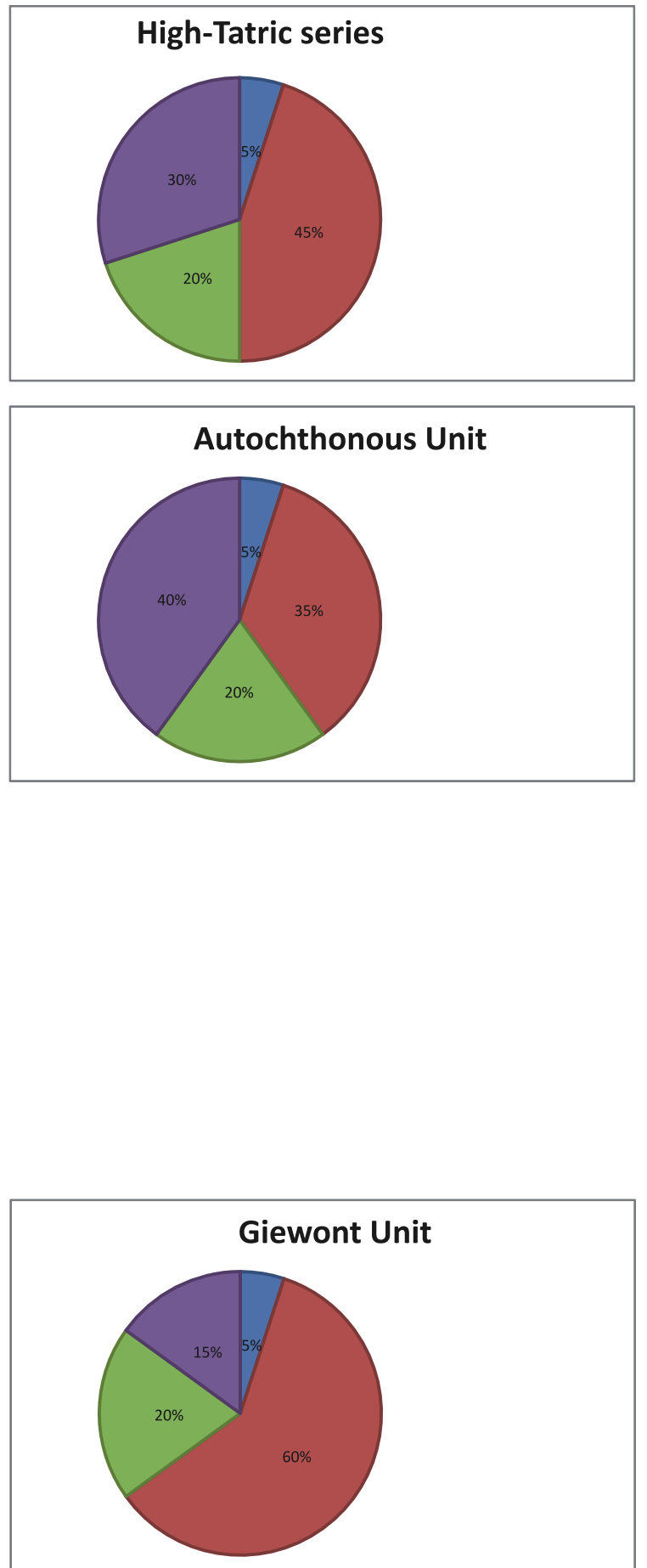

ferruginous clasts
B Krupianka Formation
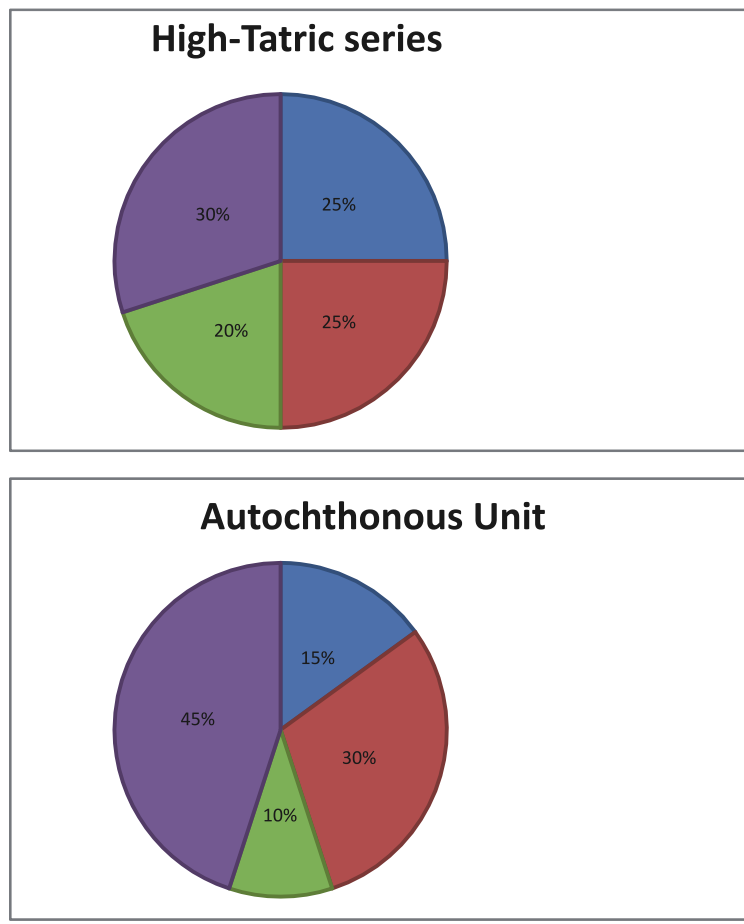

\section{Czerwone Wierchy Unit}
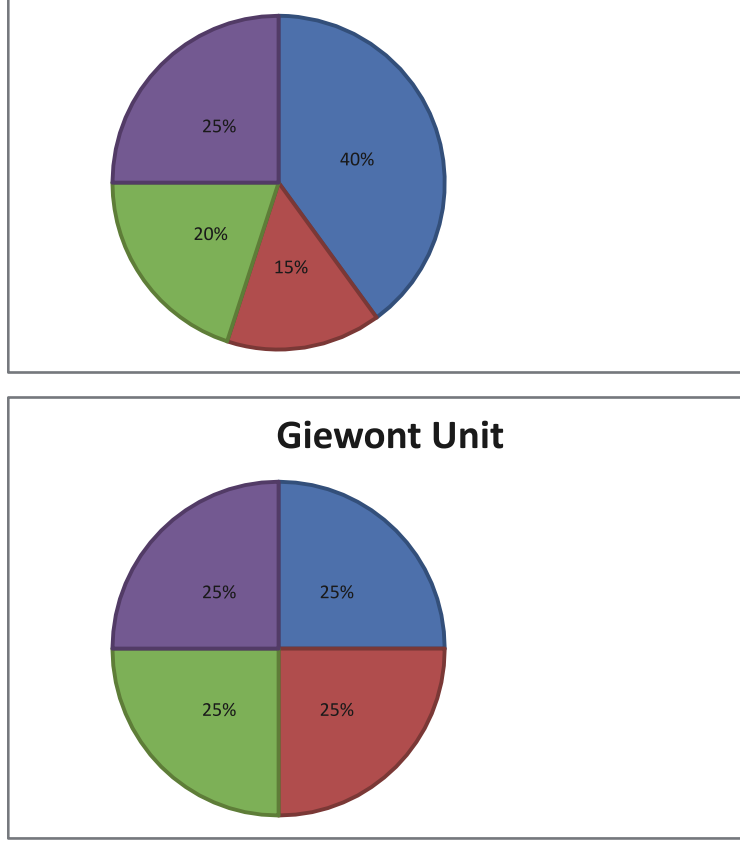

$\mathbf{a}_{\text {quartz }}$

Fig. 11. Clastic admixture in the deposits of the Smolegowa (A) and Krupianka (B) formations

episodes. The unconformities can be traced at the bases of consecutive Lower and Middle Jurassic formations. During the complex history of the High-Tatric domain in the Jurassic, including episodes of tectonic activity and erosion, particular surfaces went through several phases of development and their present outlook is an effect of their overprinting. In many places, younger surfaces cut the older, which results in a com- plex picture of spatial relations between the individual Jurassic lithosomes.

The character and origin of particular unconformity surfaces, as well as the spatial distribution of the Jurassic formations allow reconstructing the history of the High-Tatric domain in the periods corresponding to the described stratigraphic gaps. 

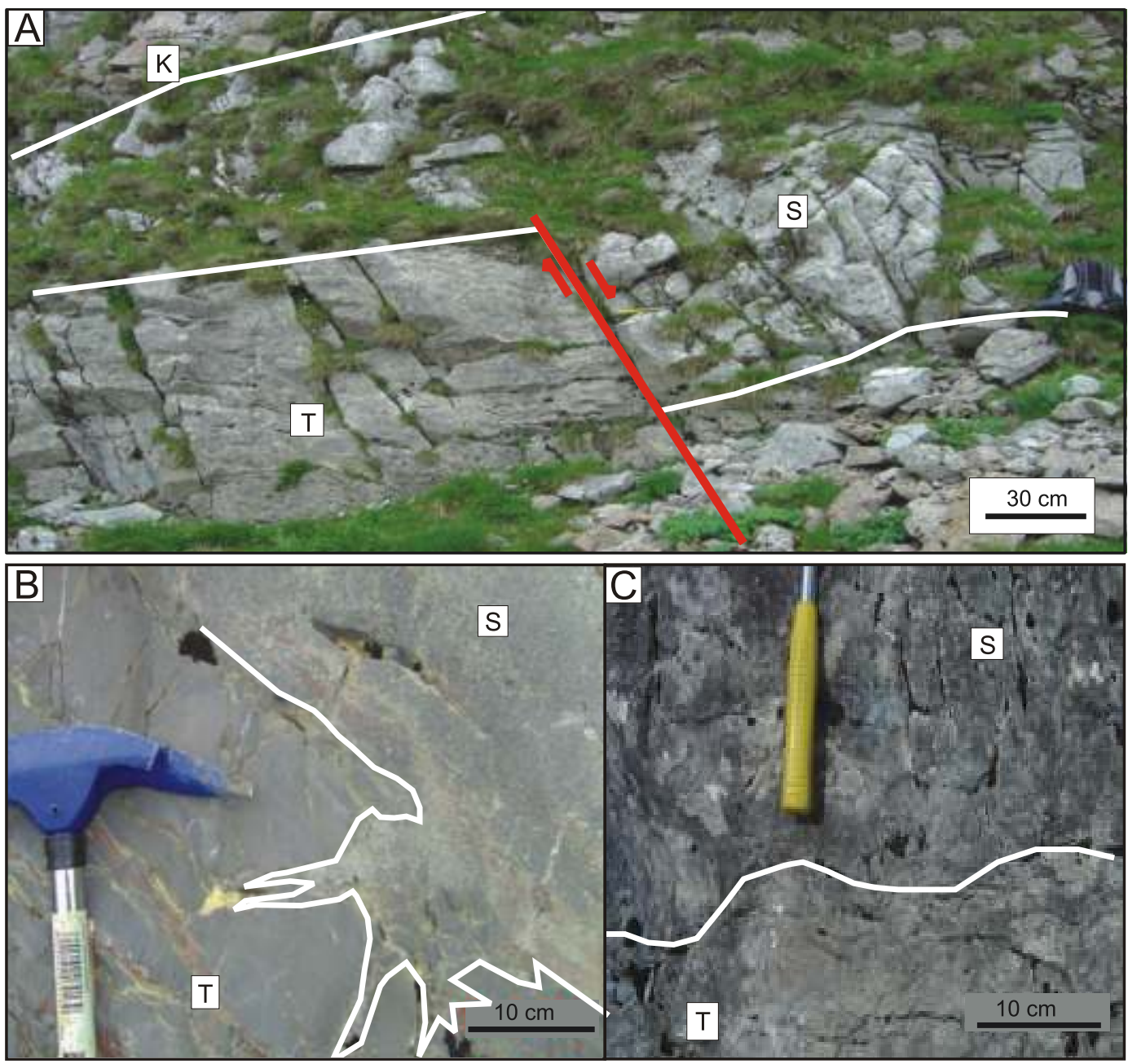

Fig. 12. Smolegowa Formation in the Giewont Unit

A - syndepositional fault, Długi Giewont 2 (2G); B - neptunian dyke penetrating the Triassic filled with the Smolegowa Formation deposits, Giewont touristic trail (Gst); C - erosional surface at the base of the Smolegowa Formation, Długi Giewont 2 (2G); T - Triassic, S - Smolegowa Formation, K - Krupianka Formation

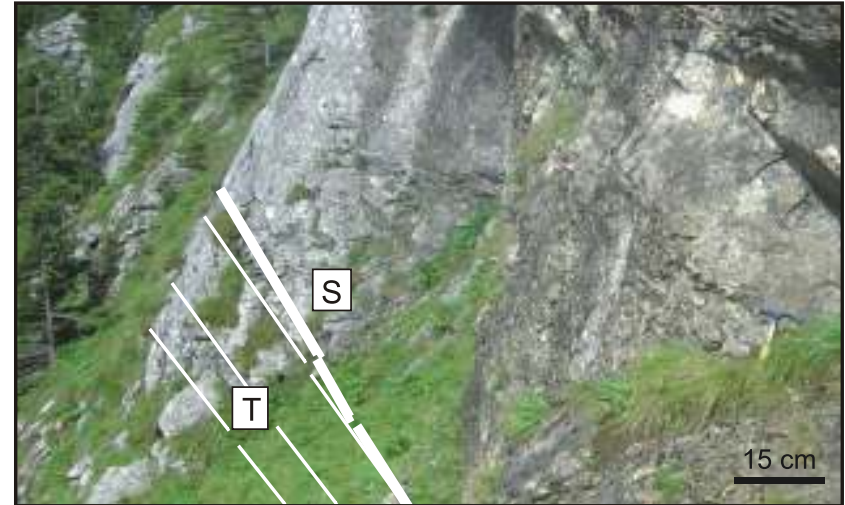

Fig. 13. Penacordant contact at the base of the Smolegowa Formation; Zawrat Kasprowy 1 (1ZK)

For explanations see Figure 10
DEVELOPMENT OF THE UNCONFORMITY AT THE BASE OF THE DUDZINIEC FORMATION

The unconformity at the base of the Dudziniec Formation is a summarized effect of two main processes:

- emersion of the whole High-Tatric Unit and erosion of the area in the Late Triassic,

- Liassic transgression resulting in several phases of abrasion in the Kominy Tylkowe Unit.

Radwański (1959) described littoral structures in the Smytnia Valley, interpreted as relicts of abrasion of an Early Jurassic cliff shore. Another symptom of considerable morphological gradients in the autochthonous unit in the Lower Jurassic is the occurrence of coarse-grained material indicating intensive erosion, as is the case in the Rzędy pod Ciemniakiem region (Fig. 4, profile $1 R Z$ ). Differentiated morphology of the High-Tatric area, and particularly of the autochthonous unit is indicated also by the fact that the Dudziniec Formation in various areas rests on different stratigraphical units of the Triassic - Norian, Anisian, or even on the so-called Werfenian (Kotański, 1956a, b; Roniewicz, 1966). 

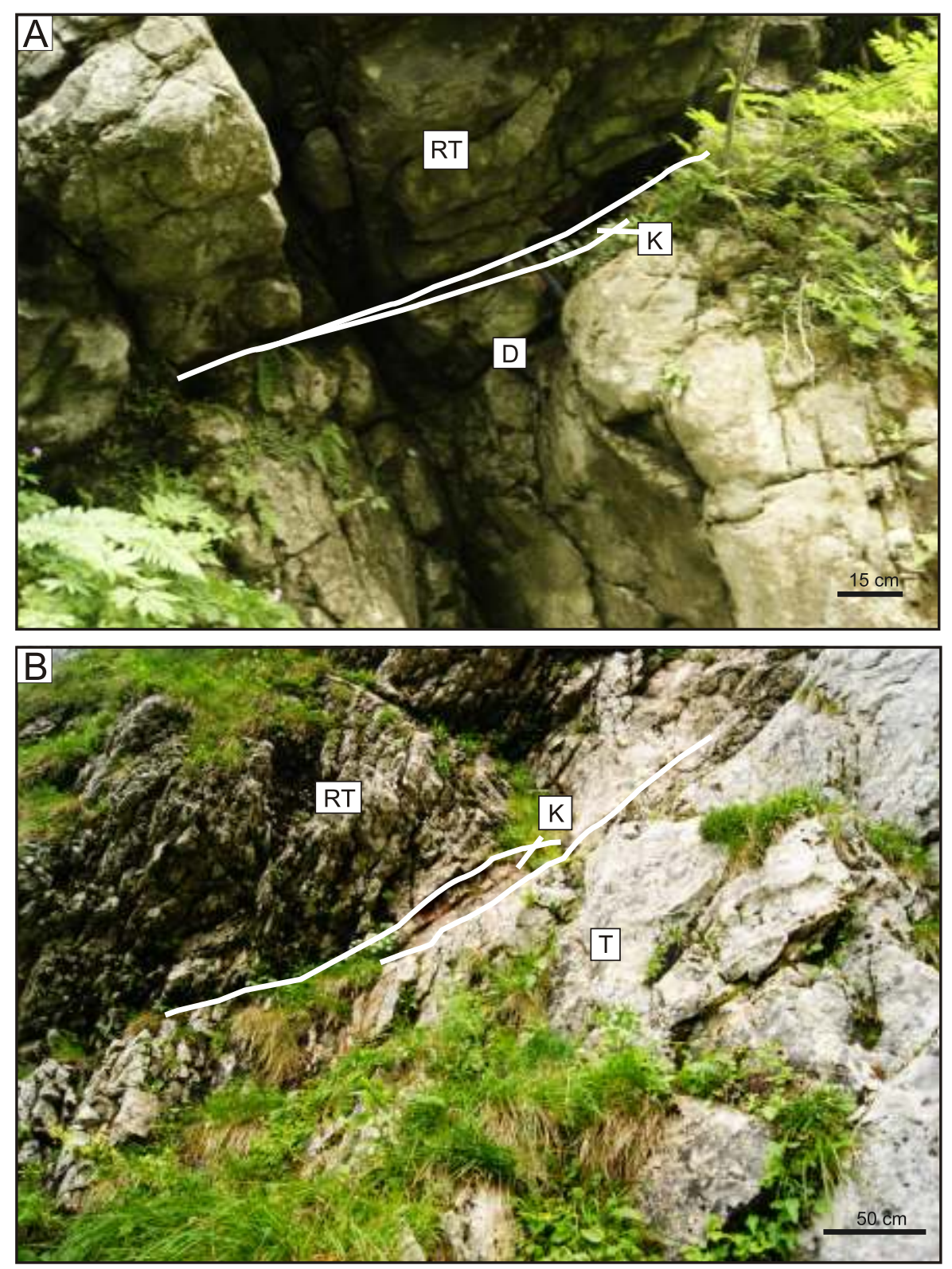

Fig. 14. Krupianka Formation preserved as laterally discontinuous lenticular bodies

A - Wąwóz Kraków gorge 1 (1WK); B - Wielka Świstówka 1 (1WŚ); T- Triassic, D - Dudziniec Formation, K - Krupianka Formation, RT - Raptawicka Turnia Formation

Only in the western part of the autochthonous unit, in the Chochołowska Valley region, the sedimentation across the Triassic-Jurassic boundary was continuous (Passendorfer, 1961; Dumont et al., 1996; Wieczorek, 2000).

The Dudziniec Formation deposits are characterized by rhythmical sedimentation. Sandy limestones, with varying fraction of clastic material, are interbedded with crinoidal limestones that also contain a substantial amount of terrigenous material (Lefeld et al., 1985). This rhythmicity was governed by recurring episodes of tectonic activity, during which the exposed areas (foldic units) were eroded and supplied clastic material to the sedimentary basin of the Kominy Tylkowe Unit. During calm episodes separating the periods of tectonic activity, the supply of clastic material diminished, which allowed the development of crinoidal meadows and the deposition of crinoidal limestones (Wójcik, 1981). Also the Liassic transgression on the autochthonous area was rhythmical, and took place in many phases, which is indicated by the occurrence of lithified Liassic intraclasts in the Dudziniec Formation. After an initial transgression, the sea receded, the accumulated deposits underwent early lithification, and finally were abraded during the following transgression. Such process probably took place several times during the deposition of the Dudziniec Formation, leading to modifications of the unconformity lying at its base.

\section{DEVELOPMENT OF THE UNCONFORMITY AT THE BASE OF THE SMOLEGOWA FORMATION}

The Liassic transgression took place only in the Kominy Tylkowe Unit (Fig. 16A). In the Early Jurassic, the Czerwone Wierchy and Giewont units were subjected to intensive erosion, 

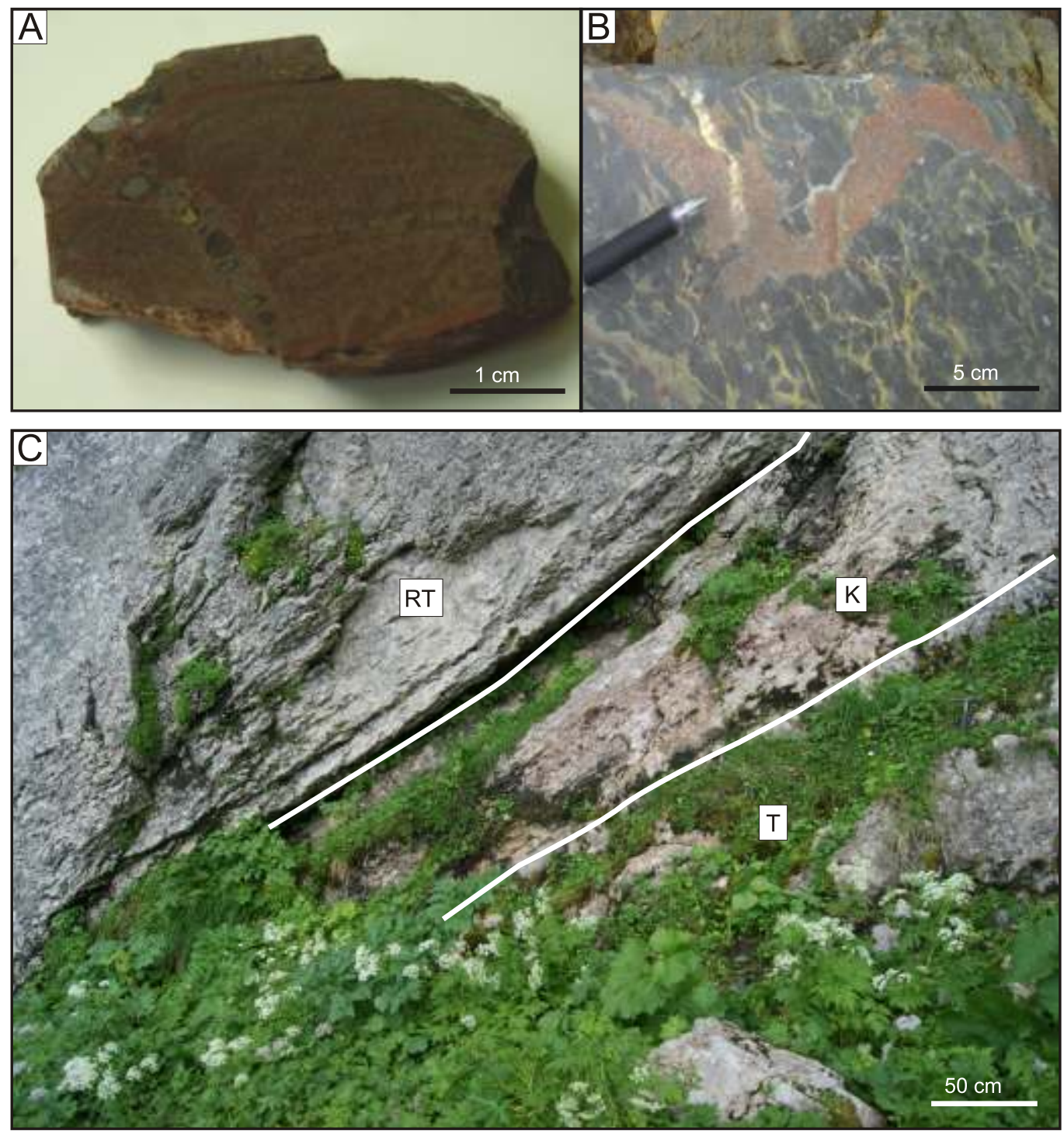

Fig. 15. Krupianka Formation

A - stromatolite, Świstówka Passendorfera (ŚP); B - neptunian dyke penetrating the Triassic filled with the Krupianka Formation deposits, Giewont touristic trail (Gst); C - contact between the Krupianka and the Raptawicka Turnia formations, Wielka Świstówka 2 (2WŚ); for other explanations see Figure 14

which in most places reached the Anisian, and acted as source areas of clastic material transported northwards to the Kominy Tylkowe area of sedimentation. The whole High-Tatric series was flooded in the Bajocian (Passendorfer, 1961).

The Bajocian transgression was probably preceded by tectonic movements leading to rotation of the whole High-Tatric area (Fig. 16B), as can be deduced from a penacordant contact of the Smolegowa Formation with the underlying Triassic in the Giewont Unit (Fig. 13). In some areas of the autochthonous unit, the deposition of the Smolegowa Formation was preceded by erosion of the Lower Jurassic deposits.

Early stages of sedimentation of the Smolegowa Formation (Fig. 17A) were characterized by high-energy levels, which is indicated e.g., by the occurrence of coarse limestone and dolomite clasts at the base of the formation in Rzędy pod Ciemniakiem (Fig. 4, profile 2RZ). During later phases of the transgression the environment became deeper and crinoidal meadows developed over large areas. In situ sedimentation of crinoidal limestones took place close to the meadows, in calm waters, below fair-weather base (Głuchowski, 1987). The crinoidal fragments are well-preserved, unbroken and accompanied by unseparated fragments of columns and arms. The recrystallised crinoidal material constitutes over $90 \%$ of the rock volume, forming almost pure encrinites with a very faint bedding or its lack. All these features suggest that the sedimentation of Bajocian crinoidal limestones was uniform in the whole High-Tatric region (Łuczyński, 2002). The in situ deposited encrinites usually develop far from the sources of terrigenous material, which means far from land, as otherwise larger amounts of terrigenous admixture interrupt the growth of crinoidal meadows. At places where the Bajocian is absent in the normal stratigraphical succession, the crinoidal limestones of the Smolegowa Formation can be found as infillings of neptunian dykes penetrating the underlying Triassic succession (Łuczyński, 2001a), as is the case in the Rzędy pod Ciemniakiem area (Fig. 4, profiles 1RZ, 2RZ, 3RZ), which is another indication that the sedimentation of these deposits took place in the whole High-Tatric area. 
\begin{tabular}{lll}
\hline A Hettangian-Aalenian & B Aalenian/Bajocian
\end{tabular}
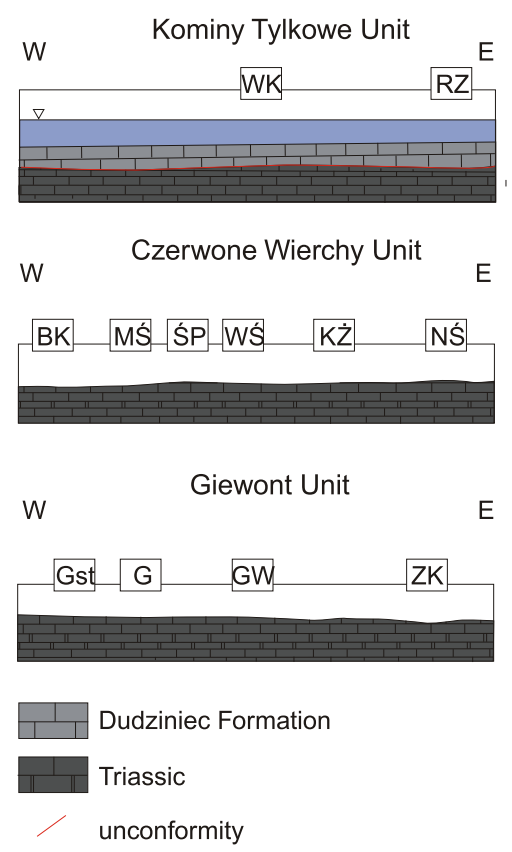

Fig. 16. Development of the High-Tatric domain

A - Early Jurassic - deposition of the Dudziniec Formation in the autochthonous unit and erosion in the Czerwone Wierchy and Giewont units; B - erosion preceding the deposition of the Smolegowa Formation; for other explanations see Figure 3

Formation of neptunian dykes with characteristic sharp-edged walls (Fig. 12B) is interpreted as being of tectonic origin, and is typical of margins of isolated carbonate platforms (Füchtbauer and Richter, 1983; Blendinger, 1986; Smart et al., 1988; Šmuc, 2010). Their development is associated with an extensional regime that prevailed in the Bajocian in the HighTatric area, and which generally resulted from palaeogeographical changes in the Central Carpathian area. The formation of extensional fissures took place in the Triassic solid substrate under the cover of recently deposited loose crinoidal deposits which were injected into the fissures directly after their opening (Winterer et al., 1991; Łuczyński, 2001a). The development of neptunian dykes in the High-Tatric area was also linked with the formation of syndepositional faults (Fig. 17A), which were responsible for differentiation of the basins topography during deposition. To some extent, the existence of such faults explains also the preservation of the Smolegowa Formation as lenticular bodies, some with a relatively considerable thickness as compared with other exposures, as in Brama Kraszewskiego (Fig. 5, profile BK). The activity of syndepositional faults lead to an increase of accommodation space in some areas and therefore in a greater thickness of the deposits (Fig. 12A).

\section{DEVELOPMENT OF THE UNCONFORMITY AT THE BASE OF THE KRUPIANKA FORMATION}

After the deposition of the Bajocian crinoidal limestones, the whole High-Tatric area became subaerially exposed and was subjected to intense erosion, which in some areas removed the entire Smolegowa Formation (Fig. 17B). The deposits of this formation are preserved only in local depressions, probably related to the activity of synsedimentary faults, and in neptunian dykes. Syndepositional faults formed probably in the autochthonous unit between the Wąwóz Kraków gorge and Rzędy pod Ciemniakiem, and in the Czerwone Wierchy Unit between Brama Kraszewskiego and Mała Świstówka in the Miętusia Valley (Fig. 17B). Small-scale syndepositional faults occur also in the Giewont Unit (Fig. 12A), however, the thickness of the Bajocian deposits in this unit does not show such variability. The strongest erosion took place in the Czerwone Wierchy Unit, in which the Smolegowa Formation in the normal stratigraphic succession is exposed only in Brama Kraszewskiego (Fig. 5, profile BK) and in Wy nia Świstówka (Grochocka-Rećko, 1963). This suggests a relatively long-lasting emersion of the Czerwone Wierchy Unit, which must have been elevated in relation to the surrounding areas. The Giewont Unit, in which the spatial thickness variability of the Middle Jurassic is least pronounced, was probably less uplifted than the surrounding areas and was subjected to smaller erosion. The synsedimentary faults that developed in the Bajocian remained active also in the Bathonian, leading to further differentiation of the sedimentary basin.

Sedimentation of the Krupianka Formation started after an episode of erosion (Fig. 18A). The deposition generally took place in an environment characterized by higher energy levels than that of the Smolegowa crinoidal limestones. This is indicated by the character of crinoidal material, with much smaller and abraded crinoidal fragments, and by a high amount of terrigenous material (Fig. 9D-F). The sedimentation area of the Krupianka crinoidal limestones was therefore located in shallower and more proximal zones, located above the areas of crinoid growth (Głuchowski, 1987). The crinoidal material was transported from the south, most probably somewhere from the Giewont Unit (Łuczyński, 2002), in which the crinoids are best preserved and the terrigenous material content is smallest. Loose crinoidal and lithoclastic material was transported on the sea bottom in the form of megaripples, which may explain the preservation of the Krupianka Formation as lenticular bodies. Episodes of non-deposition are indicated also by a gap between the opening of neptunian dykes in the Bathonian and their infilling by the Krupianka Formation deposits, as is indicted by the character of their walls commonly covered by ferruginous coats and/or calcite cements (Fig. 15B). Fissures that developed in the Triassic basement remained open until they were filled by crinoidal material transported over the sea bottom in the form of megaripples. In some areas of non-deposition, stromatolites developed, with interstices between particular domes filled by terrigenous material consisting mainly of limestone and dolomite lithoclasts (some with ferruginous coats) and of ferruginous clasts (Fig. 9G).

Intense tectonic activity in the Bathonian led to the separation of the High-Tatric area into numerous individual blocks, which subsided at different rates. An example of such succession is exposed in Świstówka Passendorfera (Fig. 5, profile ŚP), where the stromatolites are overlain by limestones with rich ammonite fauna, representing a much deeper setting. However, open marine fauna could also have been transported to the areas of isolated carbonate platforms from surrounding 
A Bajocian

B

Bajocian/Bathonian
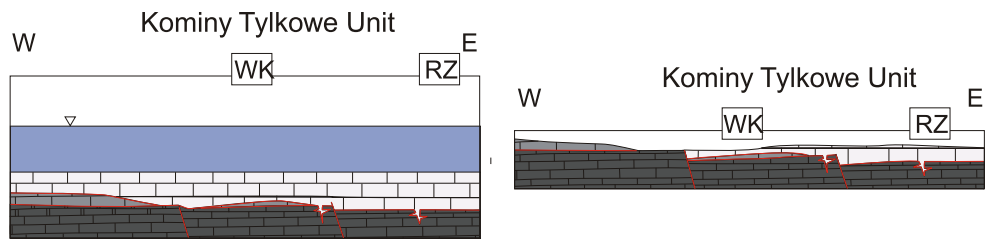

Czerwone Wierchy Unit

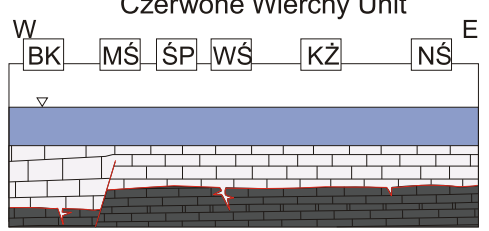
E
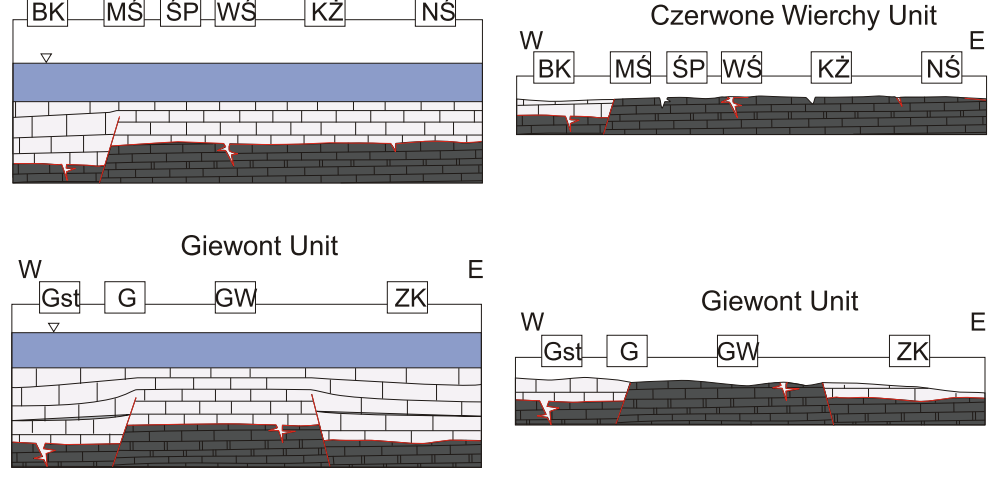

Bathonian ferruginous deposits in the Czerwone Wierchy Unit. The remaining part of the material limestone and dolomite clasts, come from erosion of the underlying Triassic rocks in areas not covered by younger deposits. The terrigenous material in the Krupianka Formation is not evenly distributed, but forms horizons indicating the occurrence of episodes of stronger tectonic activity and erosion. The same can be inferred also from the occurrence of numerous internal discontinuity surfaces within the Bathonian deposits.

Differentiated morphology during deposition and later processes of chemical compaction effected in the occurrence of three distinct lithologies of the deposits representing the Krupianka Formation. Their common feature is an intensive red colour which is linked with the occurrence of dispersed ferruginous minerals and points to low deposition rates. Numerous ferruginous coats indicate the occurrence of repeating periods of non-deposition, resulting from successive drowning of the High-Tatric region. Chemical compaction led to the development of dissolution structures and to modification of crinoidal limestones into ferruginous and nodular limestones. The thickness of the Krupianka Formation was much reduced (Łuczyński, 2001b). Also the structure of the crinoidal-lithoclast facies is an effect of chemical compaction, as is indicated by fitted fabrics and the occurrence of dissolution seams with concentrations of insoluble material, such as quartz grains.

DEVELOPMENT OF THE UNCONFORMITY AT THE BASE OF THE RAPTAWICKA TURNIA FORMATION

Fig. 17. Development of the High-Tatric domain, continued

A - deposition of the Smolegowa Formation, development of neptunian dykes and syndepositional faults; $\mathbf{B}$ - erosion preceding the deposition of the Krupianka Formation; for other explanations see Figure 3

deeper regions. In such cases, open marine fauna occurs in deposits representing a shallow environment, as is the case in Kobylarzowy leb (Fig. 5, profile 2K ).

Rich admixture of terrigenous material in the deposits of the Krupianka Formation points to the vicinity of elevated areas. The highest amount of clastic material (Fig. 11B) occurs in the eastern part of the autochthonous unit, where it reaches $15.5 \%$, somewhat lower in the Czerwone Wierchy Unit (11.7\%), and the lowest in the Giewont Unit (5.3\%). The extraclasts source area was located within the High-Tatric domain, which is indicated by their composition, as well as by a general palaeogeographical picture of the Central Carpathian region at the time. The autochthonous unit is characterized by the highest content of quartz in the admixture (45-50\%), most probably derived from erosion of the Lower Jurassic Dudziniec Formation. The erosion took place in the elevated parts of the Kominy Tylkowe Unit. The eroded material reached also the allochthonous units, in which the content of quartz grains in the admixture reaches $25 \%$. Intense erosion that took place in the Bathonian suggests that, at that time, older unconformity surfaces could have been subjected to important modifications.

The clastic material abounds also in ferruginous clasts (Fig. 11B). Their highest concentration in the Bathonian is found in the Czerwone Wierchy Unit (40\%). These clasts are probably derived from redeposition of earlier accumulated
After the deposition of the Krupianka Formation the High-Tatric area became drowned and the deposition of thick deposits of the Raptawicka Turnia Formation took place leading to relief unification (Fig. 18B). The resulting drowning of a carbonate platform effected in a considerable increase of accommodation space in relation to the amount of accumulating deposits. This, in turn, led in the Callovian to the development of the so-called drowning unconformity (Marino and Santantonio, 2010; Godet, 2013), with such characteristic features as an abrupt transition from shallow-water carbonate deposits into deep-water clastics or carbonates, and the occurrence of ferruginous coats. In some places, breaks in deposition resulted in concentration of ferruginous minerals in the bottom part of the formation, as is the case e.g., in Wielka Świstówka (Fig. 5, profile 1WŚ) in the Czerwone Wierchy Unit.

A complete geological record of drowning of a carbonate platform occurs when the shallow- and deep-water facies are separated by a drowning succession, represented by deposits with mixed benthic and planktonic fauna (Marino and Santantonio, 2010). The base and the top of such a succession respectively mark the beginning and the end of the drowning event. Commonly, the drowning succession is limited by unconformity surfaces at the bottom and the top, which laterally merge into one drowning unconformity. Usually, this is a result of a differentiated sea-bottom morphology, particularly near the edges of a carbonate platform. In the studied case, the drowning succession can be represented by crinoidal limestones of the Krupianka Formation with abundant ammonites, as is the case in Kobylarzowy leb (Fig. 5, profile 2K ). 


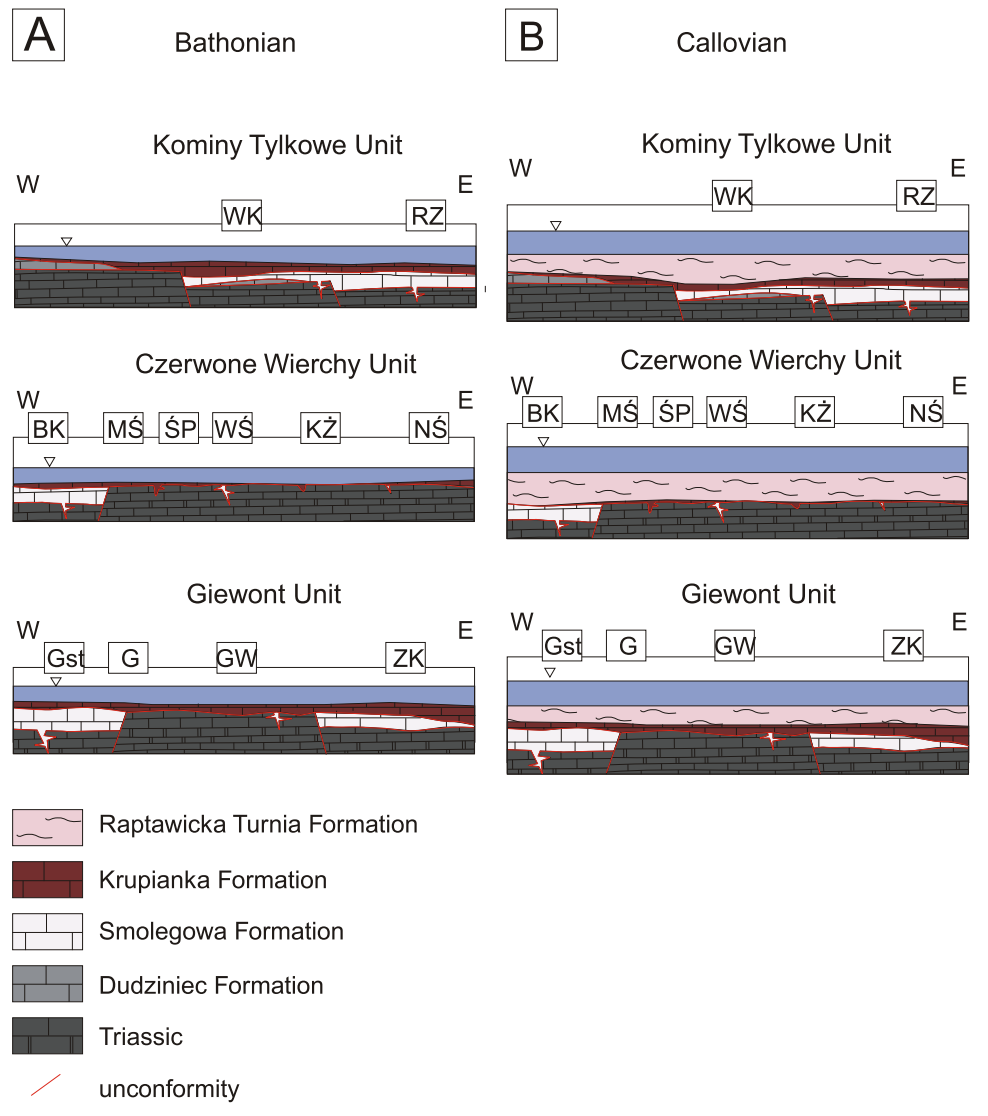

Fig. 18. Development of the High-Tatric domain, continued

A - deposition of the Krupianka Formation; B - deposition of the Raptawicka Turnia Formation; for other explanations see Figure 3

sion of subaerially exposed areas of the Czerwone Wierchy and Giewont units.

The unconformity at the base of the Smolegowa Formation has a penacordant character. Thickness variability of the formation is an effect of the activity of syndepositional faults which probably were located between the Wąwóz Kraków gorge and Rzędy pod Ciemniakiem in the autochthonous unit, and between Brama Kraszewskiego and Mała Świstówka in the Czerwone Wierchy Unit. In the Giewont Unit, syndepositional faults were less active, which is indicated by a more uniform thickness of the Bajocian in the area.

The unconformity at the base of the Krupianka Formation is erosional. The deposits contain an abundant terrigenous admixture composed of quartz grains, ferruginous clasts and lithoclasts of limestones and dolomites. Quartz grains originate from erosion of the Dudziniec Formation, which took place in the autochthonous unit. Ferruginous clasts come from erosion of the Czerwone Wierchy Unit. In the Bathonian, the Giewont Unit was an area of deposition in relatively deepest environments.

The unconformity at the base of the Raptawicka Turnia Formation is developed as a drowning unconformity which separates the underlying shallow-water facies from the overlying deeper-water sediments. The deposition of the Raptawicka Turnia Formation led to relief unification during final drowning of the High-Tatric area.

Stratigraphic gaps within the Jurassic sequence and a complex nature of spatial relations between particular Jurassic formations in the High-Tatric series have been described by Łuczyński (2002), who presented an interpretation of the palaeogeographical evolution of the region in the Middle Jurassic.

\section{DISCUSSION AND CONCLUSIONS}

The High-Tatric series of the Tatra Mountains provide an opportunity to trace the history of palaeogeographical changes taking place on the northern shelf of the Tethys Ocean during the Triassic/Jurassic boundary interval and in the Jurassic. The stratigraphical record of the Triassic and Jurassic is obscured by numerous stratigraphic gaps. In various parts of the High-Tatric Unit, the Anisian is directly overlain by the Dudziniec Formation (Sinemurian-Bajocian), the Smolegowa Formation (Bajocian), the Krupianka Formation (Bathonian) and the Raptawicka Turnia Formation (Callovian-Hauterivian). Four major unconformity surfaces have been recognised at the bases of the formations. In many places, the deposits of particular formations have been completely removed, and younger unconformity surfaces cut the older, resulting in a complex picture of the Triassic/Jurassic contact.

Detailed field studies of the contacts between the Triassic and the Jurassic and between particular Jurassic formations, performed in the autochthonous, Czerwone Wierchy and Giewont units of the High-Tatric series, supplemented by facies and microfacies analysis of Lower and Middle Jurassic deposits, and by quantitative studies of the terrigenous material, allow presenting the following conclusions:

The unconformity at the base of the Dudziniec Formation (in the autochthonous unit) is of an erosional character. The abundant clastic material has most probably been derived from ero-
In the present paper, four major unconformities corresponding to these gaps are described in detail and interpreted in terms of processes leading to their development. The general palaeogeographical picture presented by Łuczyński (2002: fig. 4 therein) remains up-to-date, however in some cases, the proposed interpretation of the unconformities described from particular areas allows presenting some minor modifications to that reconstruction, or to propose some more detailed scenarios.

A modified picture applies e.g., to the topography of the sea-bottom and the facies development of the region during the deposition of the Dudziniec and Smolegowa formations. A complex pattern of occurrence, thickness and facies development of the Dudziniec Formation, in particular the sections of the Kominy Tylkowe Unit, suggests that the morphological gradient in the area was substantial, especially at the Lower-Middle Jurassic boundary interval (Fig. 16B). The deposition of the Smolegowa Formation was influenced by the development of synsedimentary faults which are partly responsible for thickness variability of the formation (comp. Fig. 17 and Łuczyński 2002; Fig. 4).

Interpretation of the unconformity at the base of the Raptawicka Turnia Formation as a drowning unconformity indicates that, most probably, there was no emergence of the whole Czerwone Wierchy and Giewont units at the Bathonian-Callovian boundary interval, as postulated by Łuczyński (2001a, 2002). Instead of that, the whole High-Tatric area became submerged and shallow-water sedimentation of the Krupianka Formation deposits was followed by deep-water deposition of the Raptawicka Turnia Formation sediments. 
Acknowledgements. The authors wish to express their gratitude to the authorities of the Tatra National Park (Poland) for permission to conduct fieldwork and to collect samples. We also wish to thank Dr. R. Jach, Prof. M. Marino and Prof. J. Michálík for their constructive comments which helped to im- prove the paper. An important part of the paper summarizes the conclusions of A. Jezierska's M.Sc. thesis prepared at the Faculty of Geology, Warsaw University.

\section{REFERENCES}

Andrusov, D., Bystricky, J., Fusan, O., 1973. Outline of the structure of the Western Carpathians. Guide-book for the geological excursion, X Congress of the Carpathian-Balkan Geological Association: 8-15.

Bac-Moszaszwili, M., Burchart, J., Iwanow, A., Jaroszewski, W., Kotański, Z., Lefeld, J., Mastella, L., Ozimkowski, W., Roniewicz, P., Skupiński, A., Westwalewicz-Mogilska, E., 1979. Mapa geologiczna Tatr Polskich, 1:30 000 (in Polish). Wyd. Geol., Warszawa.

Birkenmajer, K., 1977. Jurassic and Cretaceous lithostratigraphic units of the Pieniny Klippen Belt, Carpathians, Poland. Studia Geologica Polonica, 40.

Blendinger, W., 1984. Late Ladinian strike-slip tectonics of the Marmolada-Costabella area (Dolomites). Jahrbuch der Geologischen Bundesanstalt, 127: 307-319.

Blendinger, W., 1986. Isolated stationary carbonate platforms: the Middle Triassic (Ladinian) of the Marmolada area, Dolomites, Italy. Sedimentology, 33: 159-184.

Clari, P.A., Dela Pierre, F., Martire, L., 1995. Discontinuities in carbonate successions: identifications, interpretation and classification of some Italian examples. Sedimentary Geology, 100: 97-21.

Cozzi, A., 2000. Synsedimentary tensional features in Upper Triassic shallow-water platform carbonates of the Carnian Prealps (northern Italy) and their importance as paleostress indicators. Basin Research, 12: 134-146.

Csontos, L., Vörös, A., 2004. Mesozoic plate tectonic reconstruction of the Carpathians region. Palaeogeography, Palaeoclimatology, Palaeoecology, 210: 1-56.

Dumont, T., Wieczorek, J., Boullin, J.P., 1996. Inverted Mesozoic rift structures in the Polish Western Carpathians (High-Tatric units). Comparison with similar features in the Western Alps. Eclogae Geologicae Helvetiae, 89: 181-202.

Dunham, R.J., 1962. Classification of carbonate rocks according to depositional texture. AAPG Memoir, 1: 108-121.

Füchtbauer, H., Richter, D.K., 1983. Relation between submarine fissures, internal breccias and mass flow during Triassic and earlier rifting periods. Geologische Rundschau, 72: 53-66.

Gaździcki, A., Michalík, J., 1980. Uppermost Triassic sequences of the Choč nappe (Hronic) in the West Carpathians of Slovakia and Poland. Acta Geologica Polonica, 30: 61-76.

Głuchowski, E., 1987. Jurassic and Early Cretaceous articulate Crinoidea from the Pieniny Klippen Belt and the Tatra Mountains, Poland. Studia Geologica Polonica, 94: 1-102.

Godet, A., 2013. Drowning unconformities: paleoenvironmental significance and involvement of global processes. Sedimentary Geology, 293: 45-66.

Grochocka-Rećko, K., 1963. Geology of Wy nia Świstówka (Western Tatra) (in Polish with English summary). Acta Geologica Polonica, 13: 239-270.

Horwitz, L., Rabowski, F., 1922. Sur le Lias et le Dogger hauttatriques de la Tatra (in Polish with French summary). Posiedzenie Naukowe Państwowego Instytutu Geologicznego, 3: $15-18$.

Jach, R., Djerić, N., Goričan, Š., Reháková, D., 2014. Integrated stratigraphy of the Middle-Upper Jurassic of the Križna Nappe, Tatra Mountains. Annales Societatis Geologorum Poloniae, $\mathbf{8 4}$ 1-33.
Jurewicz, E., 2005. Geodynamic evolution of the Tatra Mts. and the Pieniny Klippen Belt (Western Carpathians): problem and comments. Acta Geologica Polonica, 55: 295-338.

Jurewicz, E., 2012. Nappe-thrusting processes in the Tatra Mts. (in Polish with English summary). Przegląd Geologiczny, 60: 432-451.

Kostiukow, J.M., 1963. Geological mapping of Wielka Świstówka, and the Kocioł Mułowy and Litworowy cirques (in Polish with English summary). Acta Geologica Polonica, 13: 223-238.

Kotański, Z., 1956a. High-Tatric Campilian in the Tatra Mts. (in Polish with English summary). Acta Geologica Polonica, 6: 65-73.

Kotański, Z., 1956b. Stratigraphic and palaeogeographic problems in the High-Tatric Keuper (in Polish with English summary). Acta Geologica Polonica, 6: 273-286.

Kotański, Z., 1959a. Stratigraphical sections of the high-Tatric series in the Polish Tatra Mountains (in Polish with English summary). Biuletyn Instytutu Geologicznego, 139: 1-160.

Kotański, Z., 1959b. Stratigraphy, sedimentology and paleogeography of the high-tatric Triassic in the Tatra Mts. Acta Geologica Polonica, 9: 113-145.

Kotański, Z., 1961. Tectogenese et reconstitution de la paleogeographie de la zone haut-tatrique dans les Tatras (in Polish with French summary). Acta Geologica Polonica, 11: 187-476.

Lefeld, J., Gaździcki, J., Iwanow, A., Krajewski, K., Wójcik, K., 1985. Jurassic and Cretaceous lithostratigraphic units of the Tatra Mountains. Studia Geologica Polonica, 84: 1-93.

Łuczyński, P., 2001a. Development history of Middle Jurassic neptunian dykes in the High-Tatric series, Tatra Mountains, Poland. Acta Geologica Polonica, 51: 237-252.

Łuczyński, P., 2001b. Pressure solution and chemical compaction of condensed Middle Jurassic deposits, High-Tatric series, Tatra Mountains. Geologica Carpathica, 52: 91-102.

Łuczyński, P., 2002. Depositional evolution of the Middle Jurassic carbonate sediments in the High-Tatric succession, Tatra Mountains, Poland. Acta Geologica Polonica, 52: 365-378.

Marino, M., Santantonio, M., 2010. Understanding the geological record of carbonate platform drowning across rifted Tethys margin: examples from the Lower Jurassic from Apennines and Sicily (Italy). Sedimentary Geology, 225: 116-137.

Martire, L., 1996. Stratigraphy, facies and synsedimentary tectonics in the Jurassic Rosso Ammonitico Veronese (Altopiano di Asiago, NE Italy). Facies, 35: 209-236.

Michalík, J., Kováč, M., 1982. On some problems of palinspastic reconstruction and Ceno-Mesozoic development of the Western Carpathians. Geologicky Zbornik, 33: 481-507.

Murphy, M., Salvador, A., 1994. IUGS and ICG: international stratigraphic guide - anabridged version. Episodes, 22: 255-271.

Passendorfer, E., 1928. Le Kimeridgien dans la Tatra (in Polish with French summary). Sprawozdania Państwowego Instytutu Geologicznego, 4: 491-499.

Passendorfer, E., 1935. Studien über die stratigraphie und die paläontologie des hochtatrischen Jura in Tatry, I (in Polish with German summary). Rocznik Polskiego Towarzystwa Geologicznego, 11: 83-103.

Passendorfer, E., 1938. Étude sur la stratigraphie et paléontologie du Jurassique hauttatrique dans les Tatras, II (in Polish with French summary). Prace Towarzystwa Przyjaciół Nauk w Wilnie, 12: 1-9. 
Passendorfer, E., 1961. Évolution paléogéographique des Tatras (in Polish with French summary). Rocznik Polskiego Towarzystwa Geologicznego, 30: 351-387.

Plašienka, D., 1995. Passive and active margin of the northern Tatricum (Western Carpathians, Slovakia). Geologische Rundschau, 84: 748-760.

Plašienka, D., 2012. Jurassic syn-rift and Cretaceous syn-orogenic, coarse-grained deposits related to opening and closure of the Vahic (South Penninic) Ocean in the Western Carpathians - an overview. Geological Quarterly, 56 (4): 601-628.

Plašienka, D., Grecula, P., Putiš, M., Kováč, M., Hovorka, D., 1997. Evolution and structure of the Western Carpathians: an overview. Mineralia Slovaca - Monograph: 67-72.

Rabowski, F., 1959. High-Tatric series in western Tatra (in Polish with English summary). Prace Instytutu Geologicznego, 27: $1-178$.

Radwański, A., 1959. Littoral structures (cliff, clastic dikes and veins, and borings of Potamilla) in the High-Tatric Lias (in Polish with English summury). Acta Geologica Polonica, 9: 31-280.

Roniewicz, P., 1966. Lower Werfenian (Seisian) clastics in the Tatra Mts. (in Polish with English summury). Acta Geologica Polonica, 16: 1-90.

Santantonio, M., 1993. Facies associations and evolution of pelagic carbonate platform/ basin system: examples from the Italian Jurassic. Sedimentology, 40: 1039-1067.

Santantonio, M., Carminati, E., 2011. Jurassic rifting evolution of the Apennines and Southern Alps (Italy): parallels and differences. GSA Bulletin, 123: 468-484.

Schlager, W., Camber, O., 1986. Submarine slope angles, drowning unconformities, and self-erosion of limestones escarpments. Geology, 14: 762-765.
Smart, P.L., Palmer, R.J., Whitaker, F., Wright, V.P., 1988. Neptunian dykes and fissures fills: an overview and account of some modern examples. In: Paleokarst (eds. N.P. James and P.W. Choquette): 149-163. Springer, Heidelberg.

Šmuc, A., 2010. Jurassic and Cretaceous neptunian dikes in drowning succession of the Julian High (Julian Alps, NW Slovenia). Rudarsko-Metalurški Zbornik - Materials and Geoenvironment, 57: 195-214.

Szulczewski, M., 1963. The geology of Mała Świstówka in western Tatra (in Polish with English summury). Acta Geologica Polonica, 13: 199-222.

Uchman, A., 2014. Introduction - sedimentary rocks of the Tatra Mountains. In: Sedimentary Rocks of the Tatra Mountains (eds. R. Jach, T. Rychliński and A. Uchman): 12-28. Wydawnictwa Tatrzańskiego Parku Narodowego, Zakopane.

Wieczorek, J., 2000. Mesozoic evolution of the Tatra Mountains (Carpathians). Mitteilungen der Gesellschaft der Geologie und Bergbaustudenten in Wien, 44: 241-262.

Winterer, E.L., Bosellini, A., 1981. Subsidence and sedimentation of a Jurassic passive continental margin, Southern Alps. Italy. AAPG Bulletin, 65: 394-421.

Winterer, E.L., Metzler, V.C., Sarti, M., 1991. Neptunian dykes and associated breccias (Southern Alps, Italy and Switzerland): role of gravity sliding in open and closed system. Sedimentology, 38: 381-404.

Wójcik, K., 1981. Facies development of the vicinity of the Chochołowska Valley (in Polish with English summary). Przegląd Geologiczny, 39: 405-410. 